\title{
Support during pregnancy for women at increased risk of low birthweight babies \\ Review information \\ Authors
}

Ellen D Hodnett ${ }^{1}$, Suzanne Fredericks ${ }^{2}$

${ }^{1}$ Lawrence S. Bloomberg Faculty of Nursing, University of Toronto, Toronto, Canada

${ }^{2}$ School of Nursing, Ryerson University, Toronto, Canada

Citation example: Hodnett ED, Fredericks S. Support during pregnancy for women at increased risk of low birthweight babies. Cochrane Database of Systematic Reviews 2003, Issue 3. Art. No.: CD000198. DOI:

10.1002/14651858.CD000198.

\section{Contact person}

\section{Ellen D Hodnett}

Lawrence S. Bloomberg Faculty of Nursing

University of Toronto

155 College Street

Suite 130

Toronto Ontario M5T 1P8

Canada

E-mail: ellen.hodnett@utoronto.ca

\section{Dates}

\begin{tabular}{|l|l|}
\hline Assessed as Up-to-date: & 31 March 2009 \\
\hline Date of Search: & 31 March 2009 \\
\hline Next Stage Expected: & 31 May 2010 \\
\hline Protocol First Published: Issue 1, 1995 \\
\hline Review First Published: & Issue 1,1995 \\
\hline Last Citation Issue: & Issue 3, 2003 \\
\hline What's new & \\
\hline Date / Event & Description \\
\hline 31 March 2009 & Search updated. Eight new studies identified: (Bastani 2006; Cohen \\
\hline
\end{tabular}


2002; El-Khorazaty 2007; Hoyer 1994; Ickovics 2007; Lee

2009; Lumley 2006; Tough 2006). None met inclusion criteria. Beazley 2001 and Nguyen 2003 previously in awaiting classification also now excluded. Conclusions of Review unchanged. Edits were made throughout the Review.

\section{History}

\begin{tabular}{|l|l|}
\hline Date / Event & Description \\
\hline $\begin{array}{l}\text { Amended } \\
\text { Amay } 2008\end{array}$ & Converted to new review format. \\
\hline $\begin{array}{l}\text { 30 September } 2005 \\
\text { Updated }\end{array}$ & $\begin{array}{l}\text { Updated literature search resulted in addition of two included trials } \\
\text { (Brooten 2001; Dawson 1999) and two excluded studies (Ford } \\
\text { 2002; Graham 2003). The additions led to minor modifications in } \\
\text { test statistics but did not lead to changes in the conclusions of the } \\
\text { Review. }\end{array}$ \\
$\begin{array}{l}\text { Two trials await assessment (Beazley 2001; Nguyen 2003), one } \\
\text { because only a brief abstract was available and the other because } \\
\text { the reported results are for a portion of the final sample. }\end{array}$ \\
$\begin{array}{l}\text { Typos were corrected. One study ID was changed to reflect the } \\
\text { name of the primary author (Middlemiss 1989 is now identified } \\
\text { as Dawson 1989). }\end{array}$ \\
\hline
\end{tabular}

\section{Abstract}

\section{Background}

Studies consistently show a relationship between social disadvantage and low birthweight. Many countries have programs offering special assistance to women thought to be at risk for giving birth to a low birthweight infant. These programs may include advice and counseling (about nutrition, rest, stress management, alcohol and recreational drug use), tangible assistance (e.g., transportation to clinic appointments, help with household responsibilities), and emotional support. The programs may be delivered by multidisciplinary teams of health professionals, by specially trained lay workers, or by a combination of lay and professional workers.

\section{Objectives}

The objective of this review was to assess the effects of programs offering additional social support for pregnant women who are believed to be at risk for giving birth to preterm or low birthweight babies. 


\section{Search methods}

We searched the Cochrane Pregnancy and Childbirth Group's Trials Register (March 2009).

\section{Selection criteria}

Randomized trials of additional support during at-risk pregnancy by either a professional (social worker, midwife, or nurse) or specially trained lay person, compared to routine care. Additional support was defined as some form of emotional support (e.g., counseling, reassurance, sympathetic listening) and information or advice or both, either in home visits or during clinic appointments, and could include tangible assistance (e.g., transportation to clinic appointments, assistance with the care of other children at home).

\section{Data collection and analysis}

We independently assessed trial quality and extracted data. Double data entry was performed. We contacted study authors to request additional information.

\section{Results}

Eighteen trials, involving 12,658 women, were included. The trials were generally of good to excellent quality, although three used an allocation method likely to introduce bias. Programs offering additional social support for at-risk pregnant women were not associated with improvements in any perinatal outcomes, but there was a reduction in the likelihood of caesarean birth and an increased likelihood of elective termination of pregnancy. Some improvements in immediate maternal psychosocial outcomes were found in individual trials.

\section{Authors' conclusions}

Pregnant women need the support of caring family members, friends, and health professionals. While programs which offer additional support during pregnancy are unlikely to prevent the pregnancy from resulting in a low birthweight or preterm baby, they may be helpful in reducing the likelihood of caesarean birth.

\section{Plain language summary}

\section{Support during pregnancy for women at increased risk of low birthweight babies}

Programs offering additional support during pregnancy were not effective in reducing number of babies born too early and babies with low birthweights. 
Babies born to mothers in socially disadvantaged situations are more likely to be small and so have health problems. Programs providing emotional support, practical assistance, and advice have been offered in addition to usual care. The Review of 18 randomized controlled trials, involving 12,658 women, found that women who received additional support during pregnancy were less likely to have a caesarean birth and some were more likely to choose to terminate the pregnancy. However, the additional support did not reduce the likelihood of giving birth too early or that the baby was smaller than expected. There may be benefits in terms of lower anxiety and feeling better about their care.

\section{Background}

Low birthweight, usually defined as weight less than 2500 grams, is a major health problem for a baby and the baby's family, and one which consumes significant healthcare resources. In high-income countries preterm birth is the major reason for low birthweight. In low- to middle-income countries, chronic maternal malnutrition leads to large numbers of babies who are small-forgestational age (SGA) at birth (Kramer 1987). Thus "low birthweight" is an outcome that includes both infants that are born early (less than 37 weeks) or who are SGA or both. Combining babies who are born preterm with those who are SGA is problematic from a research perspective, since the underlying causes of the two problems are believed to be quite different (Kramer 1987), and treatment is different. Effective prevention of low birthweight may depend in part on its cause. Nevertheless, many countries have programs offering special assistance to women thought to be at risk of giving birth to an infant weighing less than 2500 grams. These programs may include advice and counseling (about nutrition, rest, stress management, alcohol and recreational drug use), tangible assistance (e.g. transportation to clinic appointments, help with household responsibilities), and emotional support. The programs may be delivered by multidisciplinary teams of health professionals, by specially trained lay workers, or by a combination of lay and professional workers. This Review includes all acceptably controlled trials of such programs.

Epidemiological studies consistently show a strong relationship between social disadvantage and low birthweight (Berkowitz 1993; Kramer 1987; Wilkins 1991). The underlying causal pathways are unclear, but several theoretical mechanisms have been proposed that link the physiological and psychological stress associated with social disadvantage to an increased likelihood of complications during pregnancy, fetal growth restriction, intrapartum complications, preterm birth, and poor maternal and neonatal health. Chronic poverty can lead to malnutrition, unhealthy living environments, increased risk of infection, and increased stress in daily life. 
The social stigma associated with being marginalized in society is also a source of chronic stress. Observational studies (e.g. Norbeck 1983) have suggested that social support may have a mediating influence on the relationship between life stress (regardless of the causes of the stress) and the development of pregnancy complications.

The current Review focuses on evaluations of programs for pregnant women believed to be at high risk for giving birth to a preterm or SGA baby, that have the provision of support as a major component. Readers are referred to Cochrane Reviews that have evaluated other forms of care to prevent preterm birth, SGA birth, and/or low birthweight. These Reviews have evaluated nutritional supplements, nutritional advice, interventions to assist pregnant women to stop smoking, plasma volume expansion, and various medications (Kramer 2003; Lumley 2004; Mahomed 1999; McDonald 2007; Reveiz 2007; Say 1996a; Say 1996b; Say 2001; Say 2003; Smaill 2007).

Debates have arisen regarding the relative benefits of 'professional' versus 'peer' support. Social support from a woman in one's community, who has a similar socioeconomic background and is experiencing similar life stresses, may be qualitatively different from support from a healthcare professional, who has broad professional knowledge and experience, but may not share the same socioeconomic background or life concerns, and who often provides other professional services as well as support. This Review includes studies of support by providers with varying backgrounds and qualifications.

\section{Objectives}

The primary objective was to assess the effects of programs offering additional social support compared with routine care, for pregnant women who are believed to be at high risk for giving birth to babies that are either preterm or weigh less than $2500 \mathrm{gm}$, or both, at birth. Secondary objectives were to determine whether effectiveness of support was mediated by timing of onset (early versus later in pregnancy) or type of provider (a healthcare professional or a lay woman).

\section{Methods}

\section{Criteria for considering studies for this review}

\section{Types of studies}

Inclusion criteria were: randomized controlled trial comparing a program of additional support during at-risk pregnancy by either a professional (social worker, midwife, or nurse) or a specially trained lay person, or both, in an 
effort to reduce the likelihood of preterm birth or low birthweight; random allocation to treatment and control groups.

'Additional support' was defined as some form of emotional support (e.g. counseling, reassurance, sympathetic listening) with or without additional information or advice, or both, occurring during home visits, clinic appointments, and/or by telephone. The additional support could also include tangible assistance (e.g. transportation to clinic appointments, assistance with the care of other children at home). Studies were included if the additional support was provided during pregnancy and continued until the birth of the baby, or into the postnatal period.

Trials were excluded if the intervention was solely an educational intervention or if the intervention was of brief duration (e.g. two to three weeks) and not intended to continue until the birth of the baby. Trials of smoking cessation programs or mind-body interventions for pregnant women were also excluded, as they are the foci of other Reviews (Lumley 2004; Marc 2009).

\section{Types of participants}

Pregnant women judged to be at risk of having preterm or growth-restricted babies, or both.

\section{Types of interventions}

Standardized or individualized programs of additional social support, provided in either home visits, during regular antenatal clinic visits, and/or by telephone on several occasions during pregnancy.

\section{Types of outcome measures}

The primary outcomes of interest were gestational age less than 37 weeks and birthweight lower than $2500 \mathrm{gm}$. However, the Review also includes a wide variety of neonatal and maternal outcomes that are potentially influenced by social support, including:

- miscarriage;

- pregnancy termination;

- complications during pregnancy, including fetal growth restriction and fetal distress;

- hospitalization during pregnancy;

- psychological distress during pregnancy and in the postpartum period;

- intrapartum obstetric interventions;

- operative birth;

- length of hospital stay; 
- pregnancy that results in stillbirth or neonatal death;

- pregnancy that results in other adverse neonatal outcomes, including need for specialized care and treatment;

- indicators of poor postnatal physical or mental health.

\section{Search methods for identification of studies Electronic searches}

We searched the Cochrane Pregnancy and Childbirth Group's Trials Register by contacting the Trials Search Co-ordinator (March 2009).

The Cochrane Pregnancy and Childbirth Group's Trials Register is maintained by the Trials Search Co-ordinator and contains trials identified from:

1. quarterly searches of the Cochrane Central Register of Controlled Trials (CENTRAL);

2. weekly searches of MEDLINE;

3. handsearches of 30 journals and the proceedings of major conferences;

4. weekly current awareness alerts for a further 44 journals plus monthly BioMed Central email alerts.

Details of the search strategies for CENTRAL and MEDLINE, the list of handsearched journals and conference proceedings, and the list of journals reviewed via the current awareness service can be found in the 'Specialized Register' section within the editorial information about the Cochrane Pregnancy and Childbirth Group.

Trials identified through the searching activities described above are each assigned to a review topic (or topics). The Trials Search Co-ordinator searches the register for each review using the topic list rather than keywords.

We did not apply any language restrictions.

\section{Data collection and analysis}

We evaluated trials under consideration for methodological quality and appropriateness for inclusion, without consideration of their results. For the methods used when assessing the trials identified in the previous version of this review, see Appendix 1.

For this update, we used the following methods when assessing the trials identified by the updated search (Bastani 2006; Beazley 2001; Cohen 2002; El-Khorazaty 2007; Hoyer 1994; Ickovics 2007; Lee 2009; Lumley 2006; Nguyen 2003; Tough 2006). 


\section{Selection of studies}

Both review authors independently assessed for inclusion all the potential studies we identified as a result of the search strategy. We resolved any disagreement through discussion or, if required, we consulted a third person.

\section{Data extraction and management}

We designed a form to extract data. For eligible studies, both review authors extracted the data using the agreed form. We resolved discrepancies through discussion or, if required, we consulted a third person. We entered data into Review Manager software (RevMan 2008) and checked them for accuracy.

When information regarding any of the above is unclear, we attempted to contact authors of the original reports to provide further details.

\section{Assessment of risk of bias in included studies}

Both review authors independently assessed risk of bias for each study using the criteria outlined in the Cochrane Handbook for Systematic Reviews of Interventions (Higgins 2008). Any disagreements were resolved by discussion or by involving a third assessor.

\section{(1) Sequence generation (checking for possible selection bias)}

We describe for each included study the methods used to generate the allocation sequence in sufficient detail to allow an assessment of whether it should produce comparable groups.

We assessed the methods as:

- adequate (any truly random process, e.g. random number table; computer random number generator);

- inadequate (any non random process, e.g. odd or even date of birth; hospital or clinic record number); or

- unclear.

\section{(2) Allocation concealment (checking for possible selection bias)}

We described for each included study the method used to conceal the allocation sequence in sufficient detail and determined whether intervention allocation could have been foreseen in advance of, or during recruitment, or changed after assignment. 
We assessed the methods as:

- adequate (e.g. telephone or central randomization; consecutively numbered sealed opaque envelopes);

- inadequate (open random allocation; unsealed or non-opaque envelopes, alternation; date of birth);

- unclear.

\section{(3) Blinding (checking for possible performance bias)}

We described for each included study all the methods used, if any, to blind study participants and personnel from knowledge of which intervention a participant received. We also provided information on whether the intended blinding was effective. We recognized that blinding of participants to their study group assignment would be very difficult ir not impossible. In such instances we classified a study as "partial" blinding when outcomes were selfreported by unblinded participants but recorded by blinded research personnel, and considered blinding to be adequate. Where blinding was not possible, we assessed whether the lack of blinding was likely to have introduced bias. We assessed blinding separately for different outcomes or classes of outcomes.

We assessed the methods as:

- adequate, inadequate or unclear for participants;

- adequate, inadequate or unclear for personnel;

- adequate, inadequate or unclear for outcome assessors.

\section{(4) Incomplete outcome data (checking for possible attrition bias through withdrawals, dropouts, protocol deviations)}

We described for each included study, and for each outcome or class of outcomes, the completeness of data including attrition and exclusions from the analysis. We state whether attrition and exclusions were reported, the numbers included in the analysis at each stage (compared with the total randomized participants), reasons for attrition or exclusion where reported, and whether missing data were balanced across groups or were related to outcomes. Data for a given outcome were not included if more than $20 \%$ of the data were missing or serious imbalances across study groups were present. Where sufficient information is reported, or was supplied by the trial 
authors, we re-included missing data in the analyses which we undertook. We assessed methods as:

- adequate;

- inadequate:

- unclear.

\section{(5) Selective reporting bias}

We described for each included study how the possibility of selective outcome reporting bias was examined by us and what we found.

We assessed the methods as:

- adequate (where it is clear that all of the study's pre-specified outcomes and all expected outcomes of interest to the review have been reported);

- inadequate (where not all the study's pre-specified outcomes have been reported; one or more reported primary outcomes were not pre-specified; outcomes of interest are reported incompletely and so cannot be used; study fails to include results of a key outcome that would have been expected to have been reported);

- unclear.

\section{(6) Other sources of bias}

We described for each included study any important concerns we have about other possible sources of bias. Examples of such potential sources of bias include stopping early due to a data-dependent process, extreme baseline imbalance, or claims of fraud.

We assessed whether each study was free of other problems that could put it at risk of bias:

- yes;

- no;

- unclear.

\section{(7) Overall risk of bias}

We made explicit judgements about whether studies are at high risk of bias, according to the criteria given in Table $8.5 \mathrm{c}$ of the Cochrane Handbook (Higgins 2008). With reference to (1) to (6) above, we assessed the likely magnitude and direction of the bias and whether we consider it is likely to 
impact on the findings. We plan to explore the impact of the level of bias through undertaking sensitivity analyses - see Sensitivity analysis.

\section{Measures of treatment effect}

\section{Dichotomous data}

For dichotomous data, we present results as summary risk ratio with $95 \%$ confidence intervals.

\section{Continuous data}

For continuous data, we used the weighted mean difference if outcomes are measured in the same way between trials. We used the standardized mean difference to combine trials that measure the same outcome, but use different methods.

\section{Unit of analysis issues}

\section{Cluster-randomized trials}

We planned to include cluster-randomized trials in the analyses along with individually randomized trials. Their sample sizes would have been adjusted using the methods described in Gates 2009 using an estimate of the intracluster correlation co-efficient (ICC) derived from the trial (if possible), or from another source. If ICCs from other sources are used, this will be reported and sensitivity analyses conducted to investigate the effect of variation in the ICC. If we had identified both cluster-randomized trials and individuallyrandomized trials, we planned to synthesise the relevant information. We would have considered it reasonable to combine the results from both if there were little heterogeneity between the study designs and the interaction between the effect of intervention and the choice of randomization unit was considered to be unlikely. We would also have acknowledged heterogeneity in the randomization unit and performed a separate meta-analysis.

\section{Dealing with missing data}

For included studies, levels of attrition were noted. The impact of including studies with high levels of missing data in the overall assessment of treatment effect were explored by using sensitivity analysis.

For all outcomes analyses were carried out, as far as possible, on an intention-to-treat basis, i.e. we attempted to include all participants randomized to each group in the analyses. The denominator for each outcome in each trial was the number randomized minus any participants whose outcomes are known to be missing. 


\section{Assessment of heterogeneity}

We used the $1^{2}$ statistic to measure heterogeneity among the trials in each analysis. If we identified substantial heterogeneity we planned to explore it by pre-specified subgroup analysis.

\section{Assessment of reporting biases}

Had we suspected reporting bias (see 'Selective reporting bias' above), we would have attempted to contact study authors, asking them to provide missing outcome data. Where this was not possible, and the missing data were thought to introduce serious bias, the impact of including such studies in the overall assessment of results would have been explored by a sensitivity analysis.

\section{Data synthesis}

We carried out statistical analysis using the Review Manager software (RevMan 2008). We used fixed-effect inverse variance meta-analysis for combining data where trials are examining the same intervention, and the trials' populations and methods are judged sufficiently similar. Where there is clinical or methodological heterogeneity between studies sufficient to suggest that treatment effects may differ between trials we used random-effects metaanalysis.

If substantial heterogeneity was identified in a fixed-effect meta-analysis, this was noted and the analysis repeated using a random-effects method, as a sensitivity analysis.

\section{Subgroup analysis and investigation of heterogeneity}

Subgroup analyses will be conducted when we complete the major update to the Review. The following subgroup analyses will be performed:

1. timing of onset of support (early in pregnancy versus after the first trimester is completed);

2. type of provider of support (health care professional versus lay person).

The following outcomes will be used in subgroup analysis: gestational age less than 37 weeks and birthweight less than $2500 \mathrm{gm}$.

For fixed-effect meta-analyses we conducted planned subgroup analyses classifying whole trials by interaction tests as described by Deeks 2001. For random-effects meta-analyses we assessed differences between subgroups by inspection of the subgroups' confidence intervals; non-overlapping confidence intervals indicate a statistically significant difference in treatment effect between the subgroups. 


\section{Sensitivity analysis}

Sensitivity analyses are planned when the Review undergoes a major update.

\section{Results}

\section{Description of studies}

Eighteen trials, involving 12,658 women, met the inclusion criteria; see table of 'Characteristics of included studies'. While all participants were judged to be at risk for giving birth preterm or to a low birthweight baby, the inclusion criteria defining risk status was variable. Most trials used a combination of social and obstetrical factors. The trials were conducted in Australia, Great Britain, France, Latin America, the Netherlands, South Africa, and the United States. No single outcome was reported in all 18 trials. For example, data were available from 13 trials ( $n=10,235$ participants) for birthweight lower than $2500 \mathrm{gm}$, from 11 trials ( $n=10,237$ participants) for gestational age less than 37 weeks, but from only one to two trials $(n=509$ and $n=559)$ for maternal psychosocial outcomes.

The descriptions of the additional support were generally consistent across all trials. Five trials included specific mention of education or client teaching as a component of the support (Brooten 2001; Heins 1990; Klerman 2001; McLaughlin 1992; Moore 1998). In 15 trials (Blondel 1990; Brooten 2001; Bryce 1991;Dawson 1989; Dawson 1999; Heins 1990; ledema-Kuiper 1996; Moore 1998; Norbeck 1996; Oakley 1990; Olds 1986; Rothberg 1991b; Spencer 1989; Spira 1986; Villar 1993;) the intervention consisted of one-to-one support, while in three trials (Klerman 2001; McLaughlin 1992; Rothberg 1991a), the intervention consisted of both one-to-one and group sessions. Three trials (Dawson 1989; ledema-Kuiper 1996; Spira 1986) compared care and support during home visits with inpatient hospital care.

In 12 of the 16 trials in which the support intervention was provided by a health professional (Blondel 1990; Brooten 2001; Bryce 1991; Dawson 1989; Dawson 1999; Heins 1990; ledema-Kuiper 1996; Moore 1998; Norbeck 1996; Oakley 1990; Olds 1986; Spira 1986), the provider of support was a midwife or a nurse, and in four trials (Klerman 2001; Rothberg 1991a; Rothberg 1991b; Villar 1993) the providers were social workers. In one trial (McLaughlin 1992) the support was provided by a multi-disciplinary team consisting of nurses, psychologists, midwives, and specially trained lay women. In one trial (Spencer 1989) specially trained lay women provided all of the additional support.

\section{Risk of bias in included studies}




\section{Allocation concealment}

The included trials varied in the extent to which selection bias posed a threat to validity. In one trial (McLaughlin 1992) the method of random allocation was an open list of random numbers, thus neither centrally controlled nor concealed. In one trial (Olds 1986) women drew their treatment assignments from a deck of cards, and the decks were reconstituted periodically to over represent those treatments with smaller numbers of participants. In eight trials (Blondel 1990; Bryce 1991; Klerman 2001; Norbeck 1996; Rothberg 1991a; Rothberg 1991b; Spencer 1989; Spira 1986) the method for randomization was not fully described and thus was unclear. Three trials (Bryce 1991; Norbeck 1996; Spencer 1989) used the Zelen method, in which random allocation to groups is performed before seeking group members' consent to participate. This approach could have introduced bias because of losses to follow up (higher in the experimental groups) of women who declined to participate. In five trials (Dawson 1989; Heins 1990; ledemaKuiper 1996; Oakley 1990; Villar 1993) randomization was both centrally controlled and concealed.

\section{Performance bias}

Women and their care providers could not be blinded to the presence or absence of additional support during pregnancy.

\section{Attrition bias}

Follow up for outcomes that were measured prior to hospital discharge was generally excellent, but follow up for longer-term outcomes was variable. All data entered in this Review were reported for a minimum of $80 \%$ of those originally enrolled.

\section{Effects of interventions}

Eighteen trials, involving 12,658 women, met the inclusion criteria. Social support interventions for at-risk pregnant women have not been associated with reductions in the numbers of preterm babies ( 11 trials, $n=10,237$, risk ratio $(\mathrm{RR}) 0.96,95 \%$ confidence interval $(\mathrm{Cl}) 0.86$ to 1.07 , low birthweight babies (13 trials, $n=10,235$, RR $0.98,95 \% \mathrm{Cl} 0.89$ to 1.08 ), or perinatal mortality ( 11 trials, $\mathrm{n}=9507$, $\mathrm{RR} 1.15,95 \% \mathrm{Cl} 0.89$ to 1.51$)$. The only improvement in any medical outcome of pregnancy was a decreased likelihood of caesarean birth (nine trials, $n=5108$, RR $0.88,95 \% \mathrm{Cl} 0.79$ to 0.98). Results of four trials indicate women who received additional social support were almost three times more likely to have their pregnancies terminated $(n=4195, \mathrm{RR} 2.96,95 \% \mathrm{Cl} 1.42$ to 6.17$)$. There was a possible small reduction in the use of analgesia or anaesthesia during labour and birth 
(three trials, $n=4032$, RR $0.94,95 \% \mathrm{Cl} 0.89$ to 1.00 ); although the $95 \%$ confidence interval included 1.00, there is consistency in the results of the three trials.

Individual trials have found other psychosocial benefits. Dawson 1989 reported reduced antenatal anxiety $(n=60$, mean difference (MD) -7.85 , $95 \% \mathrm{Cl}-13.14$ to -2.56$)$. Oakley 1990 found that mothers who received additional support were less likely to report being worried about their babies (RR $0.57,95 \% \mathrm{Cl} 0.39$ to 0.82). Blondel 1990 reported that mothers who received additional support were less likely to be dissatisfied with their antenatal care $(\mathrm{n}=158, \mathrm{RR} 0.42,95 \% \mathrm{Cl} 0.25$ to 0.73$)$ and less likely to report they had no help at home $(n=158, R R 0.39,95 \% \mathrm{Cl} 0.21$ to 0.73$)$.

Because in one trial $58.6 \%$ of those randomized to additional support did not accept it (Spencer 1989), funnel plots were used to explore sources of bias, and sensitivity analyses were conducted, comparing the results with and without inclusion of the trial. The funnel plots did not suggest the trial (or any other included trial) was a source of bias, and the results did not change materially when the trial was excluded.

Because there was only one trial in which the support was provided by lay women (Spencer 1989), and in another trial the support was provided by a multidisciplinary team that included lay women (McLaughlin 1992), the planned subgroup analysis was not performed. However, the results of these two trials were remarkably consistent with those of the other trials.

\section{Discussion}

In general the social support intervention was comprehensive and intensive, although timing of onset varied from the first to third trimester, with the majority of women enrolled at about mid-pregnancy. Despite the comprehensiveness of the intervention, the number and diversity of outcomes, and despite the solid theoretical rationale for linking stress, social support, and pregnancy outcome, there was no significant reduction in the likelihood of pregnancy complications, low birthweight, preterm birth, or medical complications for mother or baby in the weeks after birth. While the theoretical rationale for links between social support, stress, and health is strong, it may be that social support (regardless of the quality and quantity) is not sufficiently powerful to improve the outcomes of the pregnancy during which it is provided. An argument could be made that, given the immense social deprivation experienced by most of the women in these trials, it would be surprising if social support could have such an immediate and powerful effect. 
An alternate, or complementary, explanation for the lack of effect of social support on preterm birth or low birthweight is that our abilities to identify women who are at high risk of preterm birth or low birthweight babies are seriously limited, and thus many women were included in these trials who were not actually at higher risk of these outcomes. Furthermore, the underlying causal mechanisms linking social disadvantage to adverse pregnancy outcomes have not been identified.

Two outcomes were significantly associated with enhanced social support during pregnancy, in meta-analyses that involved several trials and over 4000 women: increased likelihood of termination of pregnancy and decreased likelihood of caesarean birth. On the assumption that the results did not occur by chance, the following interpretations are offered.

\section{(1) Termination of pregnancy}

The additional support may have resulted in women's increased awareness of the added social risk to themselves or their families, and/or their increased awareness of an increased medical risk to the baby, and thus more women were likely to take action to avoid additional problems. Also, an important aspect of social support is the provision of information. Thus, it is possible that women in the additional support group sought or received additional information, or both, about the option of pregnancy termination.

\section{(2) Caesarean birth}

It is noteworthy that the effect size is very similar to that in the Cochrane Review of support during labour (Hodnett 2007), and it is consistent with an observational study that linked social support to reduced likelihood of intrapartum complications and operative birth (Norbeck 1983).

Psychosocial outcomes were reported in few of the trials. Despite small numbers, these trials were methodologically sound and reported clear benefits in some outcomes (i.e. antenatal state anxiety, satisfaction with antenatal care, reported absence of other help at home, and feeling worried about the baby) but not in others (i.e. antenatal or postnatal depression, feeling low control postnatally). Given the number of outcomes included in the trials, it is possible that the differences occurred by chance. Alternatively, effects on psychosocial outcomes are real but the sample sizes were too small to detect important differences.

\section{Authors' conclusions Implications for practice}


Pregnant women need and deserve to have the help and support of caring family members, friends, and health professionals. However, such support is unlikely to be powerful enough to overcome the effects of a lifetime of poverty and disadvantage, or a longstanding pregnancy complication, and thereby influence the remaining course of a pregnancy. Pregnant women and their caregivers should be informed that programs which offer additional support during pregnancy are unlikely to prevent the pregnancy from resulting in a low birthweight or preterm baby, but they may be helpful in reducing the likelihood of caesarean birth.

\section{Implications for research}

There appears to be no need for further trials evaluating the medical effects of social support during pregnancy on immediate pregnancy and maternal or neonatal outcomes, or both. The possibility of improved psychosocial outcomes requires confirmation by larger trials that ensure adequate follow up of participants. Qualitative studies conducted concurrently with such trials would provide valuable information about women's evaluations of the additional support. There is an urgent priority for studies which identify the cause(s) of preterm birth. Future studies of forms of care to prevent low birthweight should differentiate between the two distinct causes of low birthweight: being born preterm and being small-for-gestational age.

\section{Acknowledgements}

We are grateful to Rita ledema-Kuiper, $\mathrm{RM}, \mathrm{PhD}$, for providing us with a copy of her PhD thesis and English summary of the trial (ledema-Kuiper 1996), and to Winnie Chu, who assisted with double-data entry and with preparation of the included and excluded trials tables, for the previous version of this Review.

\section{Contributions of authors}

Ellen Hodnett had overall responsibility for every aspect of the Review. Suzanne Fredericks performed the second data entry for the new trials in the updated Review, helped to write a draft of a revised Background, and participated in decisions regarding eligibility of trials, interpretations of the results and all other aspects of the Review.

\section{Declarations of interest}

None known.

\section{Differences between protocol and review}




\section{Published notes}

\section{Characteristics of studies}

\section{Characteristics of included studies}

\section{Blondel 1990}

\begin{tabular}{|l|l|}
\hline Methods & $\begin{array}{l}\text { RCT. Stratified by maternity unit. Random allocation was performed } \\
\text { using sealed envelopes (no other details provided). }\end{array}$ \\
\hline Participants & $\begin{array}{l}\text { 158 pregnant French women with moderate threatened preterm labour } \\
\text { between 26-36 weeks' gestation, no IV betamimetics. }\end{array}$ \\
\hline Interventions & $\begin{array}{l}\text { Control group: routine care from obstetricians or midwives at outpatient } \\
\text { clinics, no home visits, and hospitalization if necessary. } \\
\text { Experimental: 1-2 home visits/week by midwives and access to } \\
\text { domiciliary midwives via telephone, in addition to the same routine care } \\
\text { received by control group. }\end{array}$ \\
\hline Outcomes & $\begin{array}{l}\text { Hospital admission, <37 weeks' gestation at delivery, tocolytics, length } \\
\text { of hospital stay, at least 4 antenatal visits at outpatient clinic, number } \\
\text { remaining in bed all day, number with help at home, perinatal death, and } \\
\text { number who preferred home visiting system. }\end{array}$ \\
\hline Notes & \\
\hline
\end{tabular}

Risk of bias table

\begin{tabular}{|l|l|l|}
\hline Item & Judgement & Description \\
\hline Adequate sequence generation? & Unclear & \\
\hline Allocation concealment? & Unclear & B - Unclear \\
\hline Blinding? & Unclear & \\
\hline Incomplete outcome data addressed? & Unclear & \\
\hline Free of selective reporting? & Unclear & \\
\hline Free of other bias? & Unclear & \\
\hline
\end{tabular}

\section{Brooten 2001}

\begin{tabular}{|l|l|}
\hline Methods & $\begin{array}{l}\text { RCT. Random assignment using sealed envelopes prepared in advance } \\
\text { by a statisticians using a list of random numbers. After receiving } \\
\text { informed consent, a research assistant opened each envelope in turn. (No } \\
\text { other details provided.) }\end{array}$ \\
\hline Participants & $\begin{array}{l}173 \text { pregnant women at a tertiary care hospital in Philadelphia, } \\
\text { Pennsylvania, USA, at varying gestations, who were either judged to be } \\
\text { at high risk for preterm labour or had gestational or nongestational }\end{array}$ \\
\hline
\end{tabular}




\begin{tabular}{|l|l|}
\hline & diabetes, chronic hypertension or an episode of preterm labour. \\
\hline Interventions & $\begin{array}{l}\text { Control group: standard prenatal and postpartum care by residents and } \\
\text { staff physicians, for high-risk patients at the hospital clinic. No routine } \\
\text { home visits. } \\
\text { Experimental group: alternate standard clinic visits were replaced with } \\
\text { home visits by nurse specialists with master's degrees. Home visits } \\
\text { included discussion of lifestyle and psychosocial issues, as well as } \\
\text { individualized teaching and counseling. }\end{array}$ \\
\hline Outcomes & $\begin{array}{l}\text { Antenatal hospitalization; length of antenatal and postpartum hospital } \\
\text { stay; postpartum rehospitalization. }\end{array}$ \\
\hline Notes & $\begin{array}{l}\text { No neonatal outcomes are included in the Review because all results are } \\
\text { reported with the infant as the unit of analysis, and there were unequal } \\
\text { numbers of twins in the } 2 \text { groups (12 in the control group and 9 in the } \\
\text { intervention group). }\end{array}$ \\
\hline
\end{tabular}

\section{Risk of bias table}

\begin{tabular}{|l|l|l|}
\hline Item & Judgement & Description \\
\hline Adequate sequence generation? & Unclear & \\
\hline Allocation concealment? & Yes & A - Adequate \\
\hline Blinding? & Unclear & \\
\hline Incomplete outcome data addressed? & Unclear & \\
\hline Free of selective reporting? & Unclear & \\
\hline Free of other bias? & Unclear & \\
\hline
\end{tabular}

\section{Bryce 1991}

\begin{tabular}{|l|l|}
\hline Methods & $\begin{array}{l}\text { RCT via Zelen method (randomization prior to consent). No details } \\
\text { provided regarding how the random allocation was performed, other } \\
\text { than that it was done using computer-generated random numbers. }\end{array}$ \\
\hline Participants & $\begin{array}{l}1970 \text { women entered the trial in Perth, Australia. Women were eligible } \\
\text { for the trial if they had a history of 1 or more preterm births, 1 or more } \\
\text { low birthweight births, 1 or more perinatal deaths, 3 or more first } \\
\text { trimester miscarriages, 1 or more second trimester miscarriages, or an } \\
\text { antepartum hemorrhage in a previous pregnancy. }\end{array}$ \\
\hline $\begin{array}{l}\text { Control group: routine antenatal care (not described). } \\
\text { Experimental group: routine care plus home visits to provide sympathy, } \\
\text { understanding, acceptance, and affection at approximately 4-6 week } \\
\text { intervals (more frequently if the woman desired) and in-between } \\
\text { telephone calls by midwives. }\end{array}$ \\
\hline Outcomes & Gestational age at delivery, stillbirths, neonatal deaths, postneonatal \\
\hline
\end{tabular}




\begin{tabular}{|l|l|}
\hline Notes & $\begin{array}{l}\text { deaths, number of babies discharged alive, method of birth. } \\
\text { participate in the trial. Outcome data were available for all but } 3 \text { subjects } \\
\text { originally randomized (1 control and } 2 \text { experimental). }\end{array}$ \\
\hline
\end{tabular}

\section{Risk of bias table}

\begin{tabular}{|l|l|l|}
\hline Item & Judgement & Description \\
\hline Adequate sequence generation? & Yes & \\
\hline Allocation concealment? & Unclear & B - Unclear \\
\hline Blinding? & No & \\
\hline Incomplete outcome data addressed? & Unclear & \\
\hline Free of selective reporting? & Unclear & \\
\hline Free of other bias? & Unclear & \\
\hline
\end{tabular}

\section{Dawson 1989}

\begin{tabular}{|l|l|l|}
\hline Methods & $\begin{array}{l}\text { RCT. 2:1 random allocation scheme. A sealed envelope was opened by a } \\
\text { third party to reveal treatment allocation. }\end{array}$ \\
\hline Participants & $\begin{array}{l}\text { 60 pregnant women at varying stages of pregnancy, with a risk factor for } \\
\text { low birthweight baby, e.g. hypertension, IUGR, isolated small } \\
\text { antepartum bleeds, or previous perinatal loss, which would ordinarily } \\
\text { have led to hospital admission but not to immediate intervention. }\end{array}$ \\
\hline Interventions & $\begin{array}{l}\text { Control group: conventional hospital care (not described). } \\
\text { Experimental group: an average of 11 home visits by midwives plus a } \\
\text { telephone domiciliary fetal monitoring system. }\end{array}$ \\
\hline Outcomes & $\begin{array}{l}\text { Number of hospital admissions, mean gestation at delivery, days under } \\
\text { observation, numbers of nights spent in hospital, obstetric interventions } \\
\text { (inductions, caesarean delivery), maternal anxiety, postnatal depression, }\end{array}$ \\
perinatal mortality.
\end{tabular}




\section{Dawson 1999}

\begin{tabular}{|l|l|}
\hline Methods & RCT. Randomization by consecutively numbered, sealed envelopes. \\
\hline Participants & $\begin{array}{l}\text { 81 pregnant women at varying gestations, at 2 areas in South Wales, } \\
\text { believed to be at high risk for adverse pregnancy outcome but not with } \\
\text { complications likely to require acute intervention. Risk factors included } \\
\text { a poor obstetric history, hypertension, weight loss, IUGR, diminished } \\
\text { fetal movement, and minor antepartum hemorrhage. }\end{array}$ \\
\hline Interventions & $\begin{array}{l}\text { Control group: usual care, including frequent hospital clinic visits and } \\
\text { serial ultrasound scans and CTG monitoring of the fetal heart rate, fetal } \\
\text { movement, and uterine contractions. } \\
\text { Experimental group: domiciliary fetal monitoring, transmitted over the } \\
\text { phone, plus home support from community midwives. }\end{array}$ \\
\hline Outcomes & $\begin{array}{l}\text { Mean gestation at delivery, induction of labour, method of birth, } \\
\text { birthweight, Apgar scores, depression, anxiety, and satisfaction. }\end{array}$ \\
\hline Notes & $\begin{array}{l}\text { No usable outcome data regarding depression and anxiety outcomes. } \\
\text { Satisfaction outcomes were only reported for the intervention group, and } \\
\text { response rate was only 67\%. }\end{array}$ \\
\hline
\end{tabular}

Risk of bias table

\begin{tabular}{|l|l|l|}
\hline Item & Judgement & Description \\
\hline Adequate sequence generation? & Yes & \\
\hline Allocation concealment? & Yes & A - Adequate \\
\hline Blinding? & Unclear & \\
\hline Incomplete outcome data addressed? & Unclear & \\
\hline Free of selective reporting? & Unclear & \\
\hline Free of other bias? & Unclear & \\
\hline
\end{tabular}

\section{Heins 1990}

\begin{tabular}{|l|l|}
\hline Methods & $\begin{array}{l}\text { RCT. Computer-generated random numbers were put into sequentially- } \\
\text { numbered, sealed opaque envelopes at the co-ordinating centre. Upon } \\
\text { receipt of a telephone call, a lay person with no contact with patients } \\
\text { opened the envelope. }\end{array}$ \\
\hline Participants & $\begin{array}{l}\text { 1458 low-income pregnant women who attended state-funded antenatal } \\
\text { clinics, at varying gestations, free of known medical or pregnancy } \\
\text { complications, score }>9 \text { on a risk factors scale for low birthweight baby } \\
\text { or had a low birthweight infant in the previous pregnancy, in South } \\
\text { Carolina, USA. }\end{array}$ \\
\hline Interventions & Control group: usual antenatal care (not described). \\
\hline
\end{tabular}




\begin{tabular}{|l|l|}
\hline & $\begin{array}{l}\text { Experimental group: weekly or biweekly antenatal care by a nurse- } \\
\text { midwife, including education, counseling, assessment of the cervix, and } \\
\text { screening. }\end{array}$ \\
\hline Outcomes & Fetal death, birthweight. \\
\hline Notes & $\begin{array}{l}\text { The Institutional Review Board of the university determined that no } \\
\text { formal consent was necessary for entry into the study. }\end{array}$ \\
\hline
\end{tabular}

Risk of bias table

\begin{tabular}{|l|l|l|}
\hline Item & Judgement & Description \\
\hline Adequate sequence generation? & Yes & \\
\hline Allocation concealment? & Yes & A - Adequate \\
\hline Blinding? & Unclear & \\
\hline Incomplete outcome data addressed? & Unclear & \\
\hline Free of selective reporting? & Unclear & \\
\hline Free of other bias? & Unclear & \\
\hline
\end{tabular}

\section{ledema-Kuiper 1996}

\begin{tabular}{|l|l|}
\hline Methods & $\begin{array}{l}\text { RCT. Randomization centrally controlled using sealed, opaque } \\
\text { envelopes. Randomization to groups in the first half of the study was } \\
1: 1 ; \text { in the second half, 2:1 in favour of the experimental group. }\end{array}$ \\
\hline Participants & $\begin{array}{l}415 \text { high-risk pregnant women requiring daily evaluation of maternal } \\
\text { and/or fetal condition, at 3 hospitals in the Netherlands, between 1992 } \\
\text { and 1995. The main reasons for high-risk status were pregnancy induced } \\
\text { hypertension (60\% of both groups), fetal growth retardation, and } \\
\text { threatened preterm birth. }\end{array}$ \\
\hline Interventions & $\begin{array}{l}\text { Control group: admitted to hospital for daily evaluations of maternal } \\
\text { and/or fetal condition. } \\
\text { Experimental group: daily domiciliary care by a midwife, supervised by } \\
\text { a gynaecologist; care included monitoring blood pressure, urine analysis } \\
\text { and other laboratory tests, cardiotocography, and support. }\end{array}$ \\
\hline Outcomes & $\begin{array}{l}\text { Induction of labour, gestational age at delivery, mode of delivery, } \\
\text { birthweight, 5-minute Apgar score, arterial cord pH, patient satisfaction, } \\
\text { costs. }\end{array}$ \\
\hline Notes & $\begin{array}{l}\text { Information was obtained from the English summary. Efforts to obtain } \\
\text { translation of other important details are ongoing. } \\
\text { There were 46 sets of twins (20 control, 26 experimental), and analyses } \\
\text { of neonatal outcome data were based on the individual baby, rather than } \\
\text { the pregnancy, as the unit of analysis. }\end{array}$ \\
\hline
\end{tabular}




\section{Risk of bias table}

\begin{tabular}{|l|l|l|}
\hline Item & Judgement & Description \\
\hline Adequate sequence generation? & Yes & \\
\hline Allocation concealment? & Yes & A - Adequate \\
\hline Blinding? & Unclear & \\
\hline Incomplete outcome data addressed? & Unclear & \\
\hline Free of selective reporting? & Unclear & \\
\hline Free of other bias? & Unclear & \\
\hline
\end{tabular}

\section{Klerman 2001}

\begin{tabular}{|l|l|}
\hline Methods & $\begin{array}{l}\text { RCT. After written informed consent was obtained, the nurse opened a } \\
\text { sealed envelope revealing the participants' assignment to experimental } \\
\text { or control group (with approximately equal monthly assignments to both } \\
\text { groups). }\end{array}$ \\
\hline Participants & $\begin{array}{l}\text { 656 African American women who sought prenatal care from the } \\
\text { Jefferson County (Alabama) Department of Health from March 1994 to } \\
\text { June 1996 were eligible if they were: (1) African American, (2) eligible } \\
\text { for Medicaid, (3) less than 26 weeks' gestation, (4) at least 16 years old, } \\
\text { (5) score of 10 or higher on a risk assessment scale. Exclusion criteria } \\
\text { were alcoholism and substance abuse, asthma, cancer, diabetes, } \\
\text { epilepsy, high blood pressure, sickle cell disease, and HIV/AIDS. }\end{array}$ \\
\hline Interventions & $\begin{array}{l}\text { Control group: usual care by the county health department or the } \\
\text { university's obstetrics dept. No specific educational or support programs. } \\
\text { Experimental: care aimed at informing pregnant women of their risks } \\
\text { and what behaviours might improve pregnancy outcome. Women were } \\
\text { given prenatal vitamins, offered a structured smoking } \\
\text { cessation/reduction program, and offered regular meetings with a social } \\
\text { worker, to reduce stress and strengthen existing social support networks. } \\
\text { Prenatal appointments were every 2 weeks, with minimum waiting } \\
\text { times, on-site child care, evening hours, and transportation. In addition, } \\
\text { each visit included a group educational session. }\end{array}$ \\
\hline Notes & $\begin{array}{l}\text { Maternal outcomes: number of caesarean deliveries. } \\
\text { Neonatal outcomes: fetal death, mean birthweight, birthweight of } \\
\text { liveborn infants < 2500 g, mean gestational age at delivery, preterm } \\
\text { births, IUGR, Apgar score < 7 at 1 min and at 5 min, NICU stay. }\end{array}$ \\
$\begin{array}{l}\text { Outcome data not available on } 37 \text { enrolled participants (no reason } \\
\text { provided). }\end{array}$ \\
\hline Outcomes
\end{tabular}




\begin{tabular}{|l|l|l|}
\hline Item & Judgement & Description \\
\hline Adequate sequence generation? & Unclear & \\
\hline Allocation concealment? & Unclear & B - Unclear \\
\hline Blinding? & Unclear & \\
\hline Incomplete outcome data addressed? & Unclear & \\
\hline Free of selective reporting? & Unclear & \\
\hline Free of other bias? & Unclear & \\
\hline
\end{tabular}

\section{McLaughlin 1992}

\begin{tabular}{|l|l|}
\hline Methods & $\begin{array}{l}\text { RCT. After informed consent and initial interview, women were } \\
\text { randomly assigned to groups by a research assistant using a computer- } \\
\text { generated list of random numbers. }\end{array}$ \\
\hline Participants & $\begin{array}{l}428 \text { low-income women, < 28 weeks' gestation, with singleton } \\
\text { pregnancies, judged to be at risk for child maltreatment. }\end{array}$ \\
\hline Interventions & $\begin{array}{l}\text { Control group: standard medical services provided by obstetrical } \\
\text { residents at a hospital clinic. } \\
\text { Experimental: prenatal care by a multi-disciplinary team, focused on } \\
\text { psychosocial support, education, and health promotion, as well as offers } \\
\text { of individual meetings with a psychologist and prenatal support groups. }\end{array}$ \\
\hline Outcomes & $\begin{array}{l}\text { Neonatal: mean birthweight, birthweight < 2500 g. } \\
\text { Maternal: miscarriage, termination of pregnancy. }\end{array}$ \\
\hline Notes & $\begin{array}{l}\text { n=34 (15.7\%) lost to follow up from intervention group and 44 (20.9\%) } \\
\text { from control group due to spontaneous and elective abortions, twin } \\
\text { deliveries, and/or withdrawal. For an additional 13 in the experimental } \\
\text { group and 30 in the control group, only birthweight data were available. } \\
\text { Participants, healthcare providers, and data collectors were blind to } \\
\text { design and hypotheses of study. Data collectors were kept blind to } \\
\text { treatment group assignment of mothers. }\end{array}$ \\
\hline
\end{tabular}

Risk of bias table

\begin{tabular}{|l|l|l|}
\hline Item & Judgement & Description \\
\hline Adequate sequence generation? & Yes & \\
\hline Allocation concealment? & No & C - Inadequate \\
\hline Blinding? & Unclear & \\
\hline Incomplete outcome data addressed? & Unclear & \\
\hline Free of selective reporting? & Unclear & \\
\hline Free of other bias? & Unclear & \\
\hline
\end{tabular}




\section{Moore 1998}

\begin{tabular}{|l|l|}
\hline Methods & $\begin{array}{l}\text { RCT. Random assignment using sequentially numbered, sealed, opaque } \\
\text { envelopes. Clinic personnel were blinded to study group assignment, as } \\
\text { was the nurse who collected outcome data. 121 (7.8\%, 57 experimental } \\
\text { and } 64 \text { control) were dropped from final data analyses, because they had } \\
\text { either a multiple gestation, moved, or transferred to private care. }\end{array}$ \\
\hline Participants & $\begin{array}{l}1554 \text { women, between 22-32 weeks' gestation, believed to be at risk for } \\
\text { birth of a low birthweight baby, receiving prenatal care in a public clinic } \\
\text { in North Carolina, USA. All spoke English and had access to a } \\
\text { telephone. } 775 \text { were randomized to the experimental group and } 779 \text { to } \\
\text { the control group. }\end{array}$ \\
\hline $\begin{array}{l}\text { Control: a booklet about preventing preterm labour, available in the } \\
\text { clinic. } \\
\text { Experimental: instruction about the signs of preterm labour, a booklet } \\
\text { about preventing preterm labour, and 3 telephone calls/week until the } \\
\text { 37th week of gestation, by a nurse who was otherwise uninvolved with } \\
\text { the woman's care. }\end{array}$ \\
\hline Outcomes & $\begin{array}{l}\text { Low birthweight, gestational age < 37 weeks. Additional analyses were } \\
\text { performed on subgroups (younger versus older black women, younger } \\
\text { versus older white women). }\end{array}$ \\
\hline Notes & $\begin{array}{l}\text { Data are included in this Review only for outcomes of the groups } \\
\text { originally randomized, not for subgroups. }\end{array}$ \\
\hline
\end{tabular}

Risk of bias table

\begin{tabular}{|l|l|l|}
\hline Item & Judgement & Description \\
\hline Adequate sequence generation? & Unclear & \\
\hline Allocation concealment? & Yes & A - Adequate \\
\hline Blinding? & Yes & $\begin{array}{l}\text { Partial: clinic personnel and outcome assessors } \\
\text { were blinded. }\end{array}$ \\
\hline $\begin{array}{l}\text { Incomplete outcome data } \\
\text { addressed? }\end{array}$ & Unclear & \\
\hline Free of selective reporting? & Unclear & \\
\hline Free of other bias? & Unclear & \\
\hline
\end{tabular}

\section{Norbeck 1996}

Methods

RCT. Random allocation was performed using consecutively numbered, sealed envelopes. Zelen method was used: only those participants randomized to the experimental group were asked for consent. Analysis was based on intent-to-treat. 


\begin{tabular}{|l|l|}
\hline Participants & $\begin{array}{l}\text { 114 adult low-income African American women in California, USA, in } \\
\text { mid-pregnancy who were identified as having inadequate social support, } \\
\text { defined as low support from mothers or male partners. The tool used to } \\
\text { assess eligibility was the Norbeck Social Support Questionnaire; if the } \\
\text { support score from either the woman's mother or husband/partner was < } \\
28 \text { or the combined score for the 2 sources was < 36, women were } \\
\text { judged to have low support. Women were excluded if they had major } \\
\text { mental illness, therapeutic or spontaneous abortion prior to } 20 \text { weeks, or } \\
\text { were pregnant with twins. }\end{array}$ \\
\hline $\begin{array}{l}\text { Control group: standard prenatal care (not described). } \\
\text { Experimental: } 4 \text { standardized face-to-face sessions at 2 week intervals in } \\
\text { their homes, given by nurses, and telephone contacts in the intervening } \\
\text { weeks. The sessions focused on identification of problem areas and } \\
\text { successful aspects of each woman's life, her social supports, her feelings } \\
\text { about her pregnancy, and the types of relationships that foster or limit } \\
\text { self-esteem. }\end{array}$ \\
\hline Rates of low birthweight (<2500 gm). \\
\hline Outcomes & $\begin{array}{l}5(8.9 \%) \text { in the experimental group refused to participate, } 12 \% \text { received } \\
\text { only one of the formal intervention sessions, and } 77 \% \text { received } 3 \text { or } 4 \\
\text { sessions. }\end{array}$ \\
\hline Notes & \\
\hline
\end{tabular}

Risk of bias table

\begin{tabular}{|l|l|l|}
\hline Item & Judgement & Description \\
\hline Adequate sequence generation? & Yes & \\
\hline Allocation concealment? & Unclear & B - Unclear \\
\hline Blinding? & No & \\
\hline Incomplete outcome data addressed? & Unclear & \\
\hline Free of selective reporting? & Unclear & \\
\hline Free of other bias? & Unclear & \\
\hline
\end{tabular}

\section{Oakley 1990}

\begin{tabular}{|l|l|}
\hline Methods & $\begin{array}{l}\text { RCT. Random allocation, stratified by centre, via telephone call to the } \\
\text { co-ordinating centre. }\end{array}$ \\
\hline Participants & $\begin{array}{l}509 \text { women with a history of a low birthweight }(<2500 \text { gm }) \text { baby, }<24 \\
\text { weeks' gestation, singleton pregnancy, fluent in English, attending } \\
\text { antenatal booking clinics at } 4 \text { UK hospitals. The sample was socially } \\
\text { disadvantaged: } 77 \% \text { were working class, } 18 \% \text { had unemployed partners, } \\
\text { and } 41 \% \text { were smoking on entry. }\end{array}$ \\
\hline Interventions & $\begin{array}{l}\text { Control group: usual antenatal care. } \\
\text { Experimental group: usual antenatal care plus social support by the }\end{array}$ \\
\hline
\end{tabular}




\begin{tabular}{|l|l|}
\hline & $\begin{array}{l}\text { research midwife at her hospital. The social support intervention } \\
\text { consisted of, at a minimum, 3 home visits - at 14, 20, and 28 weeks' } \\
\text { gestation - plus 2 telephone contacts or brief home visits between these } \\
\text { times. The midwife was also on-call to the mothers 24 hours/day. Semi- } \\
\text { structured interview guides provided the basis for flexible and open- } \\
\text { ended communication between midwives and mothers. }\end{array}$ \\
\hline Outcomes & $\begin{array}{l}\text { Antenatal hospital admission, > 1 ultrasound scan, days in hospital } \\
\text { antenatally, admission for threatened preterm delivery, antenatal } \\
\text { hypertension, antenatal depression, method of labour onset, epidural } \\
\text { anaesthesia, labour length, type of delivery, birthweight, gestational age, } \\
\text { 5-minute Apgar score < 7, neonatal respiratory distress, admission to } \\
\text { special care nursery, days ventilated, days receiving oxygen, days totally } \\
\text { tube-fed, breastfed at discharge, neonatal problems at discharge, health } \\
\text { service use postdischarge, mother's health, mother returning to hospital } \\
\text { for non-routine postnatal care, visit to/from family doctor, postnatal } \\
\text { depression, mother feeling low/loss of control over life, worried about } \\
\text { baby, partner helpful. }\end{array}$ \\
& $\begin{array}{l}\text { After excluding twins (3 in the intervention group and } 2 \text { in the control } \\
\text { group) and spontaneous abortions (6 per group) and pregnancy } \\
\text { terminations (2 per group), data on the medical and psychosocial } \\
\text { outcomes of pregnancy, labour, and birth were available for between } \\
\text { 225-243 per group (88\%-96\%). However, the comparisons in this } \\
\text { review are based on the numbers originally randomized to each group. } \\
\text { Data from a 7-year follow-up survey of the participants (Oakley 1996) } \\
\text { are not included because responses were received from < 50\% of the } \\
\text { original sample (126 of 255 in the intervention group and 115 of 254 in } \\
\text { the control group). }\end{array}$ \\
\hline Notes & \\
\hline
\end{tabular}

Risk of bias table

\begin{tabular}{|l|l|l|}
\hline Item & Judgement & Description \\
\hline Adequate sequence generation? & Yes & \\
\hline Allocation concealment? & Yes & A - Adequate \\
\hline Blinding? & Unclear & \\
\hline Incomplete outcome data addressed? & Unclear & \\
\hline Free of selective reporting? & Unclear & \\
\hline Free of other bias? & Unclear & \\
\hline
\end{tabular}

\section{Olds 1986}

Methods

RCT. Eligible women were stratified by marital status, race, and geographic region. Women drew their treatment assignments from a deck of cards. The decks were reconstituted periodically to over represent those treatments with smaller numbers of participants. Also, in 


\begin{tabular}{|l|l|}
\hline & $\begin{array}{l}6 \text { instances women who were living with other women already enrolled } \\
\text { were assigned the same treatment condition as their housemates, and in } \\
\text { the last } 6 \text { months of the 30-month enrolment period, the number of cards } \\
\text { for treatment 4 was increased. }\end{array}$ \\
\hline Participants & $\begin{array}{l}379 \text { pregnant women in a semi-rural area in upstate New York, USA, } \\
\text { who had no previous live births, were < 30 weeks' gestation, and had } \\
\text { one or more of the following: age < 19, single parent, low } \\
\text { socioeconomic status, or nulliparous and wanting to participate. }\end{array}$ \\
\hline Interventions & $\begin{array}{l}\text { 4 groups: (1) no additional services during pregnancy, at ages 1 and 2 } \\
\text { children screened for sensory and developmental problems; (2) free } \\
\text { transportation for regular prenatal and well-child care, sensory and } \\
\text { developmental screening of the children at ages 1 and 2; (3) nurse-home } \\
\text { visitor during pregnancy plus transportation service and screening; (4) } \\
\text { the same services as in group 3, and in addition the nurse continued to } \\
\text { visit until the child was age 2. }\end{array}$ \\
\hline $\begin{array}{l}\text { Child abuse/neglect; mothers' reports of babies' moods, eating problems, } \\
\text { amount of crying and wakefulness at night; mothers' reports of } \\
\text { worry/concern, conflict, scolding, and hitting babies; number of and } \\
\text { reasons for emergency room visits for the babies; nurses' home } \\
\text { observations of mothers' avoidance of restriction and punishment and } \\
\text { mothers' provision of appropriate play materials; number of mothers } \\
\text { who graduated from or remained in high school; birthweight, length of } \\
\text { gestation, stillbirth. }\end{array}$ \\
\hline $\begin{array}{l}\text { Most of the reported results were unusable because they compared small } \\
\text { subgroups or were derived from multivariate statistical procedures. }\end{array}$ \\
$\begin{array}{l}\text { For most of the comparisons of treatments, groups 1 and 2 were } \\
\text { combined and groups 3 and 4 (nurse-visited) were combined. }\end{array}$ \\
$\begin{array}{l}\text { Data were not provided for 46 non-white women and 20 cases with } \\
\text { maternal or fetal conditions predisposing to preterm delivery and/or } \\
\text { aberrations in fetal growth, who were excluded by the authors prior to } \\
\text { data analyses. }\end{array}$ \\
\hline Notes
\end{tabular}

Risk of bias table

\begin{tabular}{|l|l|l|}
\hline Item & Judgement & Description \\
\hline Adequate sequence generation? & Unclear & \\
\hline Allocation concealment? & No & C - Inadequate \\
\hline Blinding? & Unclear & \\
\hline Incomplete outcome data addressed? & Unclear & \\
\hline Free of selective reporting? & Unclear & \\
\hline Free of other bias? & Unclear & \\
\hline
\end{tabular}




\section{Rothberg 1991a}

\begin{tabular}{|l|l|}
\hline Methods & $\begin{array}{l}\text { RCT. Random allocation via sealed envelopes which contained a green } \\
\text { or pink slip of paper. }\end{array}$ \\
\hline Participants & $\begin{array}{l}\text { 80 poor black pregnant women with hypertension and <26 weeks' } \\
\text { gestation, attending obstetric clinics serving Soweto, South Africa and } \\
\text { booked for delivery at Baragwanath Maternity Hospital, Johannesburg. }\end{array}$ \\
\hline Interventions & $\begin{array}{l}\text { Control group: routine care (not described) at the hypertension clinic and } \\
\text { routine antenatal care. } \\
\text { Experimental group: counseling by a social worker either at the time of a } \\
\text { clinic visit, in a group session, or in a home visit (or hospital visit if the } \\
\text { mother was hospitalized), on average approximately 4 times during the } \\
\text { remainder of the pregnancy. The social worker provided psychosocial } \\
\text { support and counseling, help with problems at home and at work, and } \\
\text { encouragement to comply with clinic staff instructions/advice. }\end{array}$ \\
\hline Outcomes & $\begin{array}{l}\text { Birthweight, gestational age at delivery, number hospitalized in } \\
\text { pregnancy for urgent BP control, number with proteinuria, caesarean } \\
\text { delivery, abortion/stillbirth, low birthweight rate. }\end{array}$ \\
\hline Notes & \\
\hline RiSk Of
\end{tabular}

Risk of bias table

\begin{tabular}{|l|l|l|}
\hline Item & Judgement & Description \\
\hline Adequate sequence generation? & Unclear & \\
\hline Allocation concealment? & Unclear & B - Unclear \\
\hline Blinding? & Unclear & \\
\hline Incomplete outcome data addressed? & Unclear & \\
\hline Free of selective reporting? & Unclear & \\
\hline Free of other bias? & Unclear & \\
\hline
\end{tabular}

\section{Rothberg 1991b}

\begin{tabular}{|l|l|}
\hline Methods & $\begin{array}{l}\text { RCT. Random allocation via sealed envelopes which contained a green } \\
\text { or pink slip of paper. }\end{array}$ \\
\hline Participants & $\begin{array}{l}\text { 104 Caucasian women in Johannesburg, South Africa, with a singleton } \\
\text { pregnancy between 18-25 weeks' gestation, free of medical or obstetric } \\
\text { problems known to be associated with prematurity or low birthweight, } \\
\text { and with high scores on a scale measuring life stress. }\end{array}$ \\
\hline Interventions & $\begin{array}{l}\text { Control group: usual clinic care, in which personnel were largely } \\
\text { unaware of mothers' personal problems. } \\
\text { Experimental group: a minimum of } 20 \text { minutes of individualized } \\
\text { counseling from an assigned social worker at each antenatal visit or by }\end{array}$ \\
\hline
\end{tabular}




\begin{tabular}{|l|l|}
\hline Outcomes & telephone shortly thereafter. \\
\hline Notes & $\begin{array}{l}\text { Birthweight }<3000 \text { gm, number of LBW babies, preterm rate, } \\
\text { birthweight categorized in } 500 \text { gm increments. }\end{array}$ \\
\hline $\begin{array}{l}\text { Of the original } 104 \text { randomized, } 18 \text { women }(8 \text { experimental and } 10 \\
\text { control) were dropped from the analyses. } 8 \text { mothers (4 per group) were } \\
\text { excluded for complications or because they transferred to other centres. } \\
\text { Data collection was stopped when } 43 \text { in each group had completed the } \\
\text { study. The } 4 \text { remaining mothers in the experimental group and } 6 \text { in the } \\
\text { control group continued on the study protocol, but data from these } 10 \\
\text { mothers were not included in the published reports. }\end{array}$ \\
\hline
\end{tabular}

Risk of bias table

\begin{tabular}{|l|l|l|}
\hline Item & Judgement & Description \\
\hline Adequate sequence generation? & Unclear & \\
\hline Allocation concealment? & Unclear & B - Unclear \\
\hline Blinding? & Unclear & \\
\hline Incomplete outcome data addressed? & Unclear & \\
\hline Free of selective reporting? & Unclear & \\
\hline Free of other bias? & Unclear & \\
\hline
\end{tabular}

\section{Spencer 1989}

\begin{tabular}{|l|l|}
\hline Methods & $\begin{array}{l}\text { RCT. Random allocation "using random number tables" prior to seeking } \\
\text { consent to participate from women allocated to the experimental group } \\
\text { (Zelen method). }\end{array}$ \\
\hline Participants & $\begin{array}{l}\text { 1288 pregnant women < 20 weeks' gestation and at increased risk of } \\
\text { giving birth to a low birthweight baby, booked for delivery in either of } 2 \\
\text { maternity units within the South Manchester Health District, England. } \\
\text { Asian women were excluded from the trial. Risk was defined as at least } \\
\text { 2 of the following: previous LBW baby, interpregnancy interval }<=6 \\
\text { months, underweight, previous perinatal death, > 1 previous } \\
\text { midtrimester spontaneous abortion, parity }>\text {, 3, previous } \\
\text { neonatal/infant death, single parent, woman's social class } \\
\text { IV/V/unemployed. }\end{array}$ \\
\hline $\begin{array}{l}\text { Control group: routine antenatal care (not described). } \\
\text { Experimental: client-centred approach in which social support was } \\
\text { provided by a family worker during pregnancy. The tasks of the worker } \\
\text { varied according to the individual situation, and ranged from providing } \\
\text { help in obtaining state benefits, with housing, shopping, and other } \\
\text { domestic work and child care, to promoting appropriate use of health } \\
\text { and social services and community facilities, and acting as a confidante. }\end{array}$ \\
\hline
\end{tabular}




\begin{tabular}{|l|l|}
\hline Outcomes & An average of 1-2 visits/week was provided. \\
\hline Notes & $\begin{array}{l}\text { Birthweight, length of gestation, proportions of low birthweight, small- } \\
\text { for-gestational age, and preterm births, pregnancy terminations, } \\
\text { miscarriages, still births, live births. }\end{array}$ \\
\hline $\begin{array}{l}\text { Of } 655 \text { women randomized to the experimental group, 384 (58.7\%) } \\
\text { refused the social support intervention. Comparisons of experimental } \\
\text { and control groups included all women originally randomized, except } \\
\text { for 25 controls and } 27 \text { experimentals for whom outcome data were } \\
\text { unavailable. }\end{array}$ \\
$\begin{array}{l}\text { Secondary analyses comparing those who accepted the family worker in } \\
\text { the experimental group, with those who did not accept combined with } \\
\text { the control group, showed no statistically significant differences } \\
\text { between the 2 groups. Reasons for refusal of the family worker included: } \\
\text { "already well supported" (21.8\%), "not in when visited" (13.9\%), "not } \\
\text { interested" (8.4\%), employed full time (6.3\%), moving away (6.0\%). }\end{array}$ \\
\hline
\end{tabular}

Risk of bias table

\begin{tabular}{|l|l|l|}
\hline Item & Judgement & Description \\
\hline Adequate sequence generation? & Yes & \\
\hline Allocation concealment? & No & C - Inadequate \\
\hline Blinding? & Unclear & \\
\hline Incomplete outcome data addressed? & Unclear & \\
\hline Free of selective reporting? & Unclear & \\
\hline Free of other bias? & Unclear & \\
\hline
\end{tabular}

\section{Spira 1986}

\begin{tabular}{|l|l|}
\hline Methods & RCT. Method of random allocation not described. \\
\hline Participants & $\begin{array}{l}996 \text { women with pregnancy complications that put them at risk for } \\
\text { preterm delivery, in France. }\end{array}$ \\
\hline Interventions & $\begin{array}{l}\text { Control group: hospitalized. } \\
\text { Experimental group: domiciliary care by midwives. }\end{array}$ \\
\hline Outcomes & $\begin{array}{l}\text { Birthweight, gestational age at delivery, perinatal mortality, birthweight } \\
<2500 \text { gm, }<37 \text { weeks' gestation at birth. }\end{array}$ \\
\hline Notes & $\begin{array}{l}113 \text { of the } 996(11.3 \%) \text { who were randomized were subsequently } \\
\text { excluded: } 43 \text { in the domiciliary and 70 in the hospital group. However, } \\
\text { the comparisons in this review are based on the numbers originally } \\
\text { allocated to each group. }\end{array}$ \\
\hline
\end{tabular}




\begin{tabular}{|l|l|l|}
\hline Item & Judgement & Description \\
\hline Adequate sequence generation? & Unclear & \\
\hline Allocation concealment? & Unclear & B - Unclear \\
\hline Blinding? & Unclear & \\
\hline Incomplete outcome data addressed? & Unclear & \\
\hline Free of selective reporting? & Unclear & \\
\hline Free of other bias? & Unclear & \\
\hline
\end{tabular}

\section{Villar 1993}

\begin{tabular}{|c|c|c|c|}
\hline Methods & \multicolumn{3}{|c|}{$\begin{array}{l}\text { RCT. Random allocation was carried out by the central data co- } \\
\text { ordinating centre, which produced sealed, opaque envelopes containing } \\
\text { computer-generated codes within balanced blocks of } 20 \text { women, } \\
\text { stratified by centre. }\end{array}$} \\
\hline Participants & \multicolumn{3}{|c|}{$\begin{array}{l}2235 \text { pregnant women at risk for giving birth to a low birthweight baby, } \\
\text { between } 15-22 \text { weeks' gestation, in centres in: Rosario, Argentina; } \\
\text { Pelotas, Brazil; Havana, Cuba; and Mexico City. Risk was defined as } 1 \\
\text { or more of the following: previous LBW or preterm infant, previous } \\
\text { fetal or infant death, age }<18 \text {, body weight }<=50 \mathrm{~kg} \text {, height }<=1.5 \mathrm{~m} \text {, } \\
\text { low family income according to locally adapted cutoff points, }<3 \text { years } \\
\text { of school, smoking or heavy alcohol consumption, residence apart from } \\
\text { the child's father. }\end{array}$} \\
\hline \multirow[t]{2}{*}{ Interventions } & \multicolumn{3}{|c|}{ Control group: standard antenatal care (not described). } \\
\hline & \multicolumn{3}{|c|}{$\begin{array}{l}\text { Experimental: aimed at increasing social support and reducing stress and } \\
\text { anxiety in pregnancy. A minimum of } 4 \text { home visits by specially trained } \\
\text { female social workers or obstetrical nurses. The aims of the visits were } \\
\text { to strengthen the woman's social network, and to provide direct } \\
\text { emotional support and health education. In addition, a special support } \\
\text { office - for women to visit without prior appointments or to telephone - } \\
\text { was available at each study hospital for all women in the experimental } \\
\text { group. }\end{array}$} \\
\hline Outcomes & \multicolumn{3}{|c|}{$\begin{array}{l}\text { Low birthweight, preterm delivery, IUGR, forceps delivery, caesarean } \\
\text { delivery, anaesthesia during labour, stillbirth, perinatal death, Apgar } \\
\text { score }<7 \text { at } 5 \text { minutes, admission to neonatal intensive care unit. }\end{array}$} \\
\hline \multicolumn{4}{|l|}{ Notes } \\
\hline \multicolumn{4}{|c|}{ Risk of bias table } \\
\hline \multicolumn{2}{|l|}{ Item } & Judgement & Description \\
\hline \multicolumn{2}{|c|}{ Adequate sequence generation? } & Yes & \\
\hline \multicolumn{2}{|c|}{ Allocation concealment? } & & A - Adequate \\
\hline
\end{tabular}




\begin{tabular}{|l|l|l|}
\hline Blinding? & Unclear & \\
\hline Incomplete outcome data addressed? & Unclear & \\
\hline Free of selective reporting? & Unclear & \\
\hline Free of other bias? & Unclear & \\
\hline
\end{tabular}

\section{Footnotes}

BP: blood pressure

IUGR: intrauterine growth restriction

IV: intravenous

LBW: low birthweight

min: minutes

NICU: neonatal intensive care unit

PHNs: public health nurses

RCT: randomized controlled trial

Characteristics of excluded studies

\section{Bastani 2006}

\section{Reason for exclusion Not a trial of social support during pregnancy. A trial of applied relaxation training to reduce anxiety and stress in pregnant women.}

\section{Beazley 2001}

\begin{tabular}{|l|l|}
\hline Reason for exclusion & $\begin{array}{l}\text { Abstracts, with insufficient information on which to assess trial quality. } \\
\text { When a full trial report is available, the study will be re-assessed for } \\
\text { inclusion. }\end{array}$ \\
\hline
\end{tabular}

\section{Boehm 1996}

Reason for exclusion Not a randomized trial. The control group had education, frequent prenatal visits, and cervical examinations. The 'study group' also had daily telephone contact. 'Group 3' had education but refused to participate in the study.

\section{Bullock 1995}

\begin{tabular}{|l|l|}
\hline Reason for exclusion & $\begin{array}{l}\text { Not a trial of women judged to be at risk for preterm birth or low } \\
\text { birthweight baby. The purpose was to improve pregnant women's health } \\
\text { behaviours during pregnancy. No usable or clinically interpretable } \\
\text { outcome data. Published data are mean scores (without standard } \\
\text { deviations) on measures of stress, social support, self-esteem, } \\
\text { depression, and anxiety at baseline }(<20 \text { weeks' gestation) and } 34 \\
\text { weeks' gestation. Comparisons were performed using analysis of } \\
\text { covariance. }\end{array}$ \\
\hline
\end{tabular}


Reason for exclusion Not a trial of social support during pregnancy. The intervention combined guided imagery with mindfulness-based stress reduction in a prenatal education program.

\section{Dance 1987}

Reason for exclusion

Strong likelihood of selection bias: "randomisation into intervention and control groups was decided by 'the toss of a coin' in the order in which they presented for booking, case, control, case, etc, until the 50 women had been recruited into the study", and 25 women were in each study group.

\section{El-Khorazaty 2007}

Reason for exclusion

Abstracts provide insufficient information and report differing sample sizes and differing aspects of what appears to be a multi-faceted intervention. When a full report of the trial is available, the study will be assessed again for inclusion.

Ford 2002

Reason for exclusion Strong likelihood of selection bias. A table of random numbers was used to create an open list of group assignments. Approximately the first 5 subjects at each of 5 clinics were assigned to the experimental group. There were 282 in the experimental group and 165 in the control group. Number of losses to follow up in each group are not known.

\section{Goulet 2001}

Reason for exclusion Not a trial of support during pregnancy. The intervention lasted 2 weeks and consisted of home uterine activity monitoring and additional information.

\section{Graham 1992}

Reason for exclusion

Strong likelihood of selection bias, and large loss to follow up in experimental group. An open table of random numbers was used, with odd versus even digits determining group assignment, prior to seeking consent from participants. Of the original sample of 145 women, 87 $(60 \%)$ were allocated to the experimental group and 58 to the control group. 24 women $(27.6 \%)$ in the experimental group were lost to follow up, compared to 5 women $(8.6 \%)$ in the control group.

\section{Graham 2003}

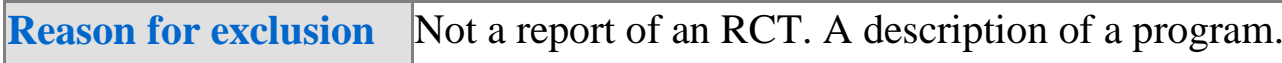


Reason for exclusion $\quad$ Not an RCT. A secondary analysis of Brooten 2001; analysis is not by group but by diagnostic category.

\section{Hobel 1994}

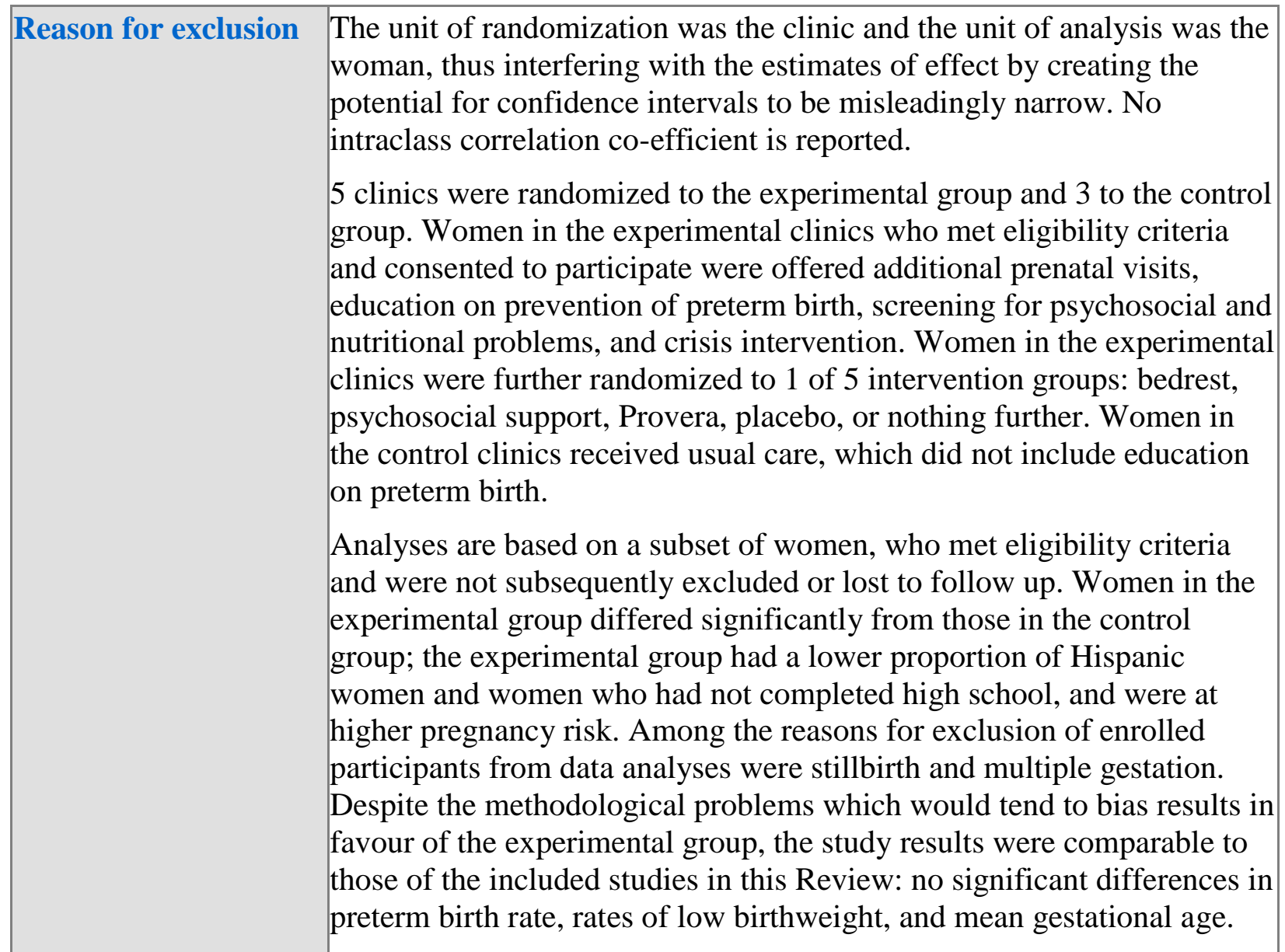

\section{Hoyer 1994}

\begin{tabular}{|l|l|}
\hline Reason for exclusion & $\begin{array}{l}\text { A letter to the editor. No indication of how many were enrolled and } \\
\text { randomized. No usable data in results (test statistics without } \\
\text { numbers). Intervention does not appear to be social support; the study } \\
\text { compared nurse-led group prenatal care with regular prenatal care by } \\
\text { physicians or other clinic practitioners. }\end{array}$
\end{tabular}

Ickovics 2007

\begin{tabular}{|l|l|}
\hline Reason for exclusion & $\begin{array}{l}\text { The intervention was not social support. The study compared } \\
\text { individually-provided prenatal care with prenatal care provided in } \\
\text { groups. Group prenatal care was hypothesized to decrease HIV risk } \\
\text { behaviours and STD transmission. The report is a secondary analysis to } \\
\text { determine whether group prenatal care leads to better reproductive } \\
\text { health outcomes. }\end{array}$ \\
\hline
\end{tabular}




\section{Kitzman 2000}

Reason for exclusion

This study compared 2 groups of women who had received prenatal and infancy home visitation 3 years ago, and was a follow up to determine the effectiveness of the program on their maternal life course. The purpose was not to evaluate the immediate impact of provision of additional support to high-risk pregnant women during prenatal and postpartum care.

\section{Koniak-Griffin 2000}

\section{Reason for exclusion}

Not a trial of additional pregnancy support. Both study groups received 1-2 antenatal home visits by a nurse. The experimental group received additional visits during the year after birth. Also, although the sample was small $(n=144)$, there was prognostic stratification on 5 variables. And there may have been some attrition bias: 144 adolescents were originally enrolled, with no information about how many were in each group, and outcomes are reported for $95 \%-98 \%$ of the 121 who complied through the first 6 postpartum weeks, with no information about how many of the 23 withdrawals were in each group.

\section{Lee 2009}

\section{Reason for exclusion}

Not a trial of social support in pregnancy. Report is of a subset of pregnant women who were part of a larger trial to evaluate a public health program in New York, USA, which included pre and postnatal home visits. The purpose of the program was to prevent child abuse and neglect. Of 1297 originally randomized, only 501 (38.6\%) (236 and 265 in each group) were included in this secondary analysis.

\section{Little 2002}

Reason for exclusion Large losses to follow up; outcome data available for just $70 \%$ of those originally randomized. Compared to those retained in the analyses, those excluded were more likely to be multiparous, single, Caucasian, and to possess less than college-level education. Of those retained in the analyses, the control group had disproportionately more twin pregnancies (11.9\% versus $3.3 \%)$.

\section{Lumley 2006}

Reason for exclusion Not a trial of social support in pregnancy. The intervention was prepregnancy advice and counseling.

\section{Nguyen 2003}

Reason for exclusion

Not a trial of social support. Both groups received home visits in pregnancy, and the difference was in the training of the home visitors. 


\begin{tabular}{|l|l|}
\hline & $\begin{array}{l}\text { One group received visits by a "traditional" public health nurse and the } \\
\text { other by a public health nurse with advanced training. The objective was } \\
\text { to increase women's self-efficacy. High risk of bias in method of } \\
\text { randomization. }\end{array}$ \\
\hline
\end{tabular}

Oakley 1996

\begin{tabular}{|l|l|}
\hline Reason for exclusion & $\begin{array}{l}\text { This report describes the results of a 7-year follow-up postal survey of } \\
\text { the participants in an earlier trial (Oakley 1990). Data were available for } \\
\text { fewer than 50\% of the trial participants (126 of } 255 \text { in the intervention } \\
\text { group and } 115 \text { of } 254 \text { in the control group). }\end{array}$ \\
\hline
\end{tabular}

Tough 2006

Reason for exclusion

The aim was to improve use of healthcare resources. There were 3 groups, 1 of which received social support by home visitors during pregnancy. No usable clinical outcome data. Primary objective was to measure the use of community-based, pregnancy-related resources, including prenatal and parenting classes, breastfeeding supports, and nutrition counseling.

\section{Footnotes}

RCT: randomized controlled trial

STD: sexually transmitted disease

\section{Characteristics of studies awaiting classification}

\section{Footnotes}

\section{Characteristics of ongoing studies}

\section{Footnotes}

\section{Summary of findings tables}

\section{Additional tables}

\section{References to studies}

\section{Included studies}

\section{Blondel 1990}

* Blondel B, Breart G, Llado J, Chartier M. Evaluation of the home-visiting system for women with threatened preterm labor: results of a randomized controlled trial. European Journal of Obstetrics \& Gynecology and Reproductive Biology 1990;34:47-58. 
Blondel B, Llado J, Breart G. Prevention of preterm deliveries by home visiting system: results of a French randomized controlled trial. In: Proceedings of International Symposium on Advances in the Prevention of Low Birthweight; 1988 May 8-11; Cape Cod, Massachusetts, USA. 1988:141-50.

\section{Brooten 2001}

Brooten D, Youngblut JM, Brown L, Finkler SA, Neff DF, Madigan E. A randomized trial of nurse specialist home care for women with high-risk pregnancies: outcomes and costs. American Journal of Managed Care $2001 ; 7(8): 793-803$.

\section{Bryce 1991}

Bryce R. Support in pregnancy. International Journal of Technology Assessment in Health Care 1991;7(4):478-84.

* Bryce RL, Stanley FJ, Garner JB. Randomized controlled trial of antenatal social support to prevent preterm birth. British Journal of Obstetrics and Gynaecology 1991;98:1001-8.

Stanley F, Bryce R. The pregnancy home visiting program. In: Papernik E, Breart G, Spira N, editor(s). Prevention of preterm birth. Vol. 138. Paris: Colloque INSERM, 1986:309-28.

\section{Dawson 1989}

* Dawson AJ, Middlemiss C, Coles EC, Gough NAJ, Jones ME. A randomized study of a domiciliary antenatal care scheme: the effect on hospital admissions. British Journal of Obstetrics and Gynaecology 1989;96:1319-22. Middlemiss C, Dawson A, Gough N, Jones M, Coles E. A randomised study of a domiciliary antenatal care scheme: maternal psychological effects. Midwifery 1989;5:69-74.

\section{Dawson 1999}

Dawson A, Cohen D, Candelier C, Jones G, Sanders J, Thompson A et al. Domiciliary midwifery support in high-risk pregnancy incorporating telephonic fetal heart rate monitoring: a health technology randomized assessment. Journal of Telemedicine \& Telecare 1999;5(4):220-30.

\section{Heins 1990}

Heins H, Nance N, McCarthy B, Efird C, Collaborative Group. The South Carolina multicentered randomized controlled trial to reduce low birthweight. In: Proceedings of International Symposium on Advances in the Prevention of 
Low Birthweight; 1988 May 8-11; Cape Cod, Massachusetts, USA. 1988:8799.

Heins $\mathrm{H}$, Nance N. A statewide randomized clinical trial to reduce the incidence of low birth weight/very low birth weight infants in South Carolina. In: Papiernik E, Breart N, Spira N, editor(s). Prevention of preterm birth. Vol. 138. Paris: Colloque INSERM, 1986:387-410.

* Heins HC, Nance NW, McCarthy BJ, Efird CM. A randomized trial of nursemidwifery prenatal care to reduce low birth weight. Obstetrics \& Gynecology 1990;75:341-5.

\section{ledema-Kuiper 1996}

Unpublished data only

* Iedema-Kuiper HR, Bruinse HW, Peddemors HE, Reuwer HM, Merkus WN, v.d. Salm PCM et al. The Utrecht domiciliary care in high risk pregnancies study: the effect of hospital admission days, fetal and maternal outcome, maternal well being and cost-effectiveness: a randomized study. Prenatal and Neonatal Medicine 1996;1 Suppl 1:10.

ledema-Kuiper HR. Geintegreerde Thuiszorg bij Risicozwangeren [Domiciliary care in high risk pregnancies] [PhD thesis]. Utrecht: University of Utrecht, 1996.

\section{Klerman 2001}

Klerman LV, Ramey SL, Goldenberg RL, Marbury S, Hou J, Cliver SP. A randomized trial of augmented prenatal care for multiple-risk, medicaideligible African American women. American Journal of Public Health 2001;91(1):105-11.

\section{McLaughlin 1992}

McLaughlin FJ, Altemeier WA, Christensen MJ, Sherrod KB, Dietrich MS, Stern DT. Randomized trial of comprehensive prenatal care for low-income women: effect on infant birth weight. Pediatrics 1992;89(1):128-32.

\section{Moore 1998}

* Moore ML, Meis PJ, Ernest JM, Wells HB, Zaccaro DJ, Terrell T. A randomized trial of nurse intervention to reduce preterm and low birth weight births. Obstetrics \& Gynecology 1998;91:656-61.

Moore ML, Meis PJ, Ernest JM. Reducing low birthweight birth through intensive nursing intervention via telephone. American Journal of Obstetrics and Gynecology 1994;170:383. 
Muender MM, Moore ML, Chen GJ, Sevick MA. Cost-benefit of a nursing telephone intervention to reduce preterm and low-birthweight births in an African American clinic population. Preventive Medicine 2000;30(4):271-6.

\section{Norbeck 1996}

Norbeck JS, DeJoseph JF, Smith RT. A randomized trial of an empiricallyderived social support intervention to prevent low birthweight among African American women. Social Science and Medicine 1996;43:947-54. [MEDLINE: 1997043266]

\section{Oakley 1990}

* Oakley A, Rajan L, Grant AM. Social support and pregnancy outcome. British Journal of Obstetrics and Gynaecology 1990;97:155-62.

Oakley A, Rajan L. The social support and pregnancy outcome study. In: Proceedings of International Symposium on Advances in the Prevention of Low Birthweight; 1988 May 8-11; Cape Cod, Massachusetts, USA. 1988:12338.

Rajan L, Oakley A. Infant feeding practice in mothers at risk of low birth weight delivery. Midwifery 1990;6:18-27.

Rajan L, Oakley A. Low birth weight babies: the mother's point of view. Midwifery 1990;6:73-85.

\section{Olds 1986}

Olds D, Henderson C, Phelps C, Kitzman H, Hanks C. Effect of prenatal and infancy nurse home visitation on government spending. Medical Care 1993;31(2):155-74.

Olds D, Henderson C, Tatelbaum R, Chamberlin R. Improving the life-course development of socially disadvantaged mothers: a randomized trial of nurse home visitation. American Journal of Public Health 1988;78:1426-45.

* Olds D, Henderson R, Chamberlin R, Tatelbaum R. Preventing child abuse and neglect: a randomized trial of nurse home visitation. Pediatrics 1986;78(1):65-78.

Olds DL, Henderson CR, Tatelbaum R, Chamberlin R. Improving the delivery of prenatal care and outcomes of pregnancy: a randomized trial of nurse home visitation. Pediatrics 1986;77:16-28. [MEDLINE: 1986066978]

\section{Rothberg 1991a}


Rothberg AD, Lits $B$, Shuenyane $E$. Effects of counselling on birthweight in two Johannesburg communities. In: Proceedings of the 10th Conference on Priorities in Perinatal Care; 1991; South Africa. 1991:103-6.

Rothberg AD, Shuenyane E, Sefuba M. Psychosocial support for mothers with pregnancy-related hypertension: effect on birthweight. Pediatric Reviews and Communications 1991;6:13-20.

Rothberg AD, Shuenyane El, Lits B, Strebel PM. Effect of stress on birth weight in two Johannesburg populations. South African Medical Journal 1991;79:35-8.

${ }^{*}$ Rothberg AD. Efffects of stress and counselling on birthweight in two Johannesburg communities [PhD thesis]. Johannesburg, South Africa: University of Witwatersrand, 1991.

\section{Rothberg 1991b}

Rothberg AD, Lis B, Shuenyane E. Effects of counselling on birthweight in two Johannesburg communities. In: Proceedings of the 10th Conference on Priorities in Perinatal Care; 1991; South Africa. 1991:103-6.

${ }^{*}$ Rothberg AD, Lits B. Psychosocial support for maternal stress during pregnancy: Effect on birth weight. American Journal of Obstetrics and Gynecology 1991;165:403-7. [MEDLINE: 1991336337]

Rothberg AD. Effects of stress and counselling on birthweight in two Johannesburg communities [PhD thesis]. Johannesburg, South Africa: University of Witwatersrand, 1991.

\section{Spencer 1989}

Spencer B, Morris J. The family worker project: social support in pregnancy. In: Papiernik E, Breart G, Spira N, editor(s). Prevention of preterm birth. Vol. 138. Paris: Colloque INSERM, 1986:363-82.

* Spencer B, Thomas H, Morris J. A randomized controlled trial of the provision of a social support service during pregnancy: the South Manchester Family Worker Project. British Journal of Obstetrics and Gynaecology 1989;96:281-8.

Spencer B. The family workers project: evaluation of a randomized controlled trial of a pregnancy social support service. In: Proceedings of International Symposium on Advances in the Prevention of Low Birthweight; 1988 May 811; Cape Cod, Massachusetts, USA. 1988:109-21.

\section{Spira 1986}

Published and unpublished data 
* Spira N, Audras F, Chapel A, Debuisson J, Jacquelin C, Kirchhoffer C et al. Domiciliary care of pathological pregnancies by midwives. Comparative controlled study on 996 women. Journal de Gynecologie, Obstetrique et Biologie de la Reproduction (Paris) 1981;10:543-8.

Spira N. Evaluation of prenatal home visiting midwives program. In: Papiernik E, Breart G, Spira N, editor(s). Prevention of Preterm Birth. Vol. 138. Paris: Colloque INSERM, 1986:291-308.

\section{Villar 1993}

Belizan JM, Barros F, Langer A, Farnot U, Victora C, Villar J. Impact of health education during pregnancy on behavior and utilization of health resources. Latin American Network for Perinatal and Reproductive Research. American Journal of Obstetrics and Gynecology 1995;173:894-9. [MEDLINE: 1996013412]

Langer A, Garcia C, Leis T, Reynoso S, Hernandez B. Psychosocial support in pregnancy as a strategy to promote the newborn's health (translation). Revista de Investigacion Clinica 1993;45:317-28.

Langer A, Victora C, Victora M, Barros F, Farnot U, Belizan J et al. The Latin American trial of psychosocial support during pregnancy: a social intervention evaluated through an experimental design. Social Science and Medicine 1993;36(4):495-507.

Victora CG, Langer A, Barros F, Belizan J, Farnot U, Villar J. The Latin American multicenter trial on psychosocial support during pregnancy: methodology and baseline comparability. Latin American Network for Perinatal and Reproductive Research (LANPER). Controlled Clinical Trials 1994;15:379-94.

* Villar J, Farnot U, Barros B, Victora C, Langer A, Belizan J. A randomized trial of psychosocial support during high-risk pregnancies. New England Journal of Medicine 1992;327:1266-71.

\section{Excluded studies}

\section{Bastani 2006}

* Bastani F, Hidarnia A, Kazemnejad A, Vafaei M, Kashanian M. A randomized controlled trial of the effects of applied relaxation training on reducing anxiety and perceived stress in pregnant women. Journal of Midwifery \& Women's Health 2005;50(4):e36-e40.

Bastani F, Hidarnia A, Montgomery KS, Aguilar-Vafaei ME, Kazemnejad A. Does relaxation education in anxious primigravid Iranian women influence 
adverse pregnancy outcomes? A randomized controlled trial. Journal of Perinatal \& Neonatal Nursing 2006;20(2):138-46.

\section{Beazley 2001}

Beazley D, Mercer B, Meyer N, Carr T. The Memphis preterm birth project: prediction and prevention of preterm birth in extremely high risk women [abstract]. American Journal of Obstetrics and Gynecology 2001;185(6):S86S87.

Mercer B, Beazley D, Klesges L, Meyer N, Carr T. Weekly nurse contact to prevent preterm birth: impact of maternal stressors and perceived stress [abstract]. American Journal of Obstetrics and Gynecology 2002;187(6 Pt 2):S128.

\section{Boehm 1996}

Boehm FH, Glass CA, Reed GW. Prevention of preterm birth. Role of daily telephone contact. Journal of Reproductive Medicine 1996;41(8):595-601.

\section{Bullock 1995}

Bullock LFC, Wells E, Duff GB, Hornblow AR. Telephone support for pregnant women: outcome in late pregnancy. New Zealand Medical Journal 1995;108:476-8.

\section{Cohen 2002}

Cohen JI. Effects of an intervention program to decrease distress in pregnant Latina women at risk for preterm birth [thesis]. Los Angeles: University of California, 2002.

\section{Dance 1987}

Dance J. A social intervention by linkworkers to Pakistani women and pregnancy outcome. M.A. Sociological Research in Health Care, Marston Green Maternity Hospital: Birmingham, University of Warwick July 1987.

\section{El-Khorazaty 2007}

El-Mohandes AAE, Kiely M, Gantz MG, El-Khorazaty N. A multiple risk factor behavioral intervention reduces environmental tobacco smoke exposure. Pediatric Academic Societies Annual Meeting; 2007 May 5-8; Toronto, Canada 2007.

El-Mohandes AAE. A psycho-behavioral intervention on African American pregnant women with a history of intimate partner violence (IPV) improves birth weight distribution of their newborns [abstract]. In: Pediatric Academic 
Societies Annual Meeting; 2006 April 29-May 2; San Francisco, CA, USA. 2006.

El-Mohandes AAE. An integrated behavioral intervention reduces rates of moderate and extreme prematurity in African American (AA) mothers with a history of smoking during pregnancy [abstract]. In: Pediatric Academic Societies Annual Meeting; 2006 April 29-May 2; San Francisco, CA, USA. 2006.

Joseph J, for NIH-DC initiative to reduce infant mortality. Randomized trial to reduce 4 behaviors linked to adverse pregnancy outcomes among 1048 innercity African American women [abstract]. In: Pediatric Academic Societies Annual Meeting; 2005 May 14-17; Washington DC, USA. 2005:Abstract no: 1701.

Joseph J. Overall effects of a behavioral intervention to reduce pregnancy risks among 1044 African American women in Washington DC: results of a randomized clinical trial [abstract]. In: Pediatric Academic Societies Annual Meeting; 2006 April 29-May 2; San Francisco, CA, USA. 2006.

Katz K, Subramanian S, Rodan M, Schwartz D, El-Khorazaty N, El-Mohandes A, et al. Randomized controlled trial (RCT) of depression counseling for lowincome African American (AA) women in prenatal care [abstract]. In: Pediatric Academic Societies Annual Meeting; 2005 May 14-17; Washington DC, USA. 2005:Abstract no: 1715.

Subramanian S, the NIH-DC Initiative. Pregnancy and infant outcomes in a multi center, randomized controlled trial for psychosocial risks (PS) in urban, low income African American women (AA) [abstract]. In: Pediatric Academic Societies Annual Meeting; 2005 May 14-17; Washington DC, USA. 2005:Abstract no: 881.

\section{Ford 2002}

Published and unpublished data

Ford K, Weglicki L, Kershaw T, Schram C, Hoyer PJ, Jacobson ML. Effects of a prenatal care intervention for adolescent mothers on birth weight, repeat pregnancy, and educational outcomes at one year postpartum. Journal of Perinatal Education 2002;11(1):35-8.

\section{Goulet 2001}

Goulet C, Gevry H, Gauthier RJ, Lepage L, Fraser W, Aita M. A controlled clinical trial of home care management versus hospital care management for preterm labour. International Journal of Nursing Studies 2001;38:259-69. 
Goulet C, Gevry H, Lemay M, Gauthier RJ, Lepage L, Fraser W. A randomized clinical trial of care for women with preterm labour: home management vs. hospital management. CMAJ: Canadian Medical Association Journal 2001;164(7):985-91.

\section{Graham 1992}

Graham A, Frank S, Zyzanski S, Kitson G, Reeb K. A clinical trial to decrease the rate of low birth weight in an inner-city black population. Family Medicine 1992;24(6):439-46.

\section{Graham 2003}

Graham M, Stabile S, Powell A, Pruett R, Zervigon Hakes A, Butler B. Serving pregnant women within early head start: lessons from the panhandle healthy start and early head start.

http://www.ehsnrc.org/InformationResources/ResourceArticles/ftpreg.htm (accessed 15 July 2003).

\section{Hamilton 2002}

Hamilton MS, Brooten D, Youngblut JM. High-risk pregnancy: postpartum rehospitalization. Journal of Perinatology 2002;22:566-71.

\section{Hobel 1994}

* Hobel C, Ross M, Bennis R, Bragonier J, Nessim S, Sandhu M et al. The West Los Angeles preterm birth prevention project: I. Program impact on highrisk women. American Journal of Obstetrics and Gynecology 1994;170:54-62.

Hobel C, Siega-Riz A. The West Los Angeles Preterm Birth Prevention Project: a reassessment of interventions. Prenatal and Neonatal Medicine 1998;3:161-4.

Hobel CJ, Bemis RL. The West Area Los Angeles prematurity prevention demonstration project. In: Papiernik E, Breart G, Spira N, editor(s). Prevention of preterm birth. Vol. 138. Paris: Colloque INSERM, 1986:205-22.

Hobel CJ, Bragonier R, Ross M, Bear M, Bemis R, Mori B. West Los Angeles premature prevention program: significant impact. Journal of Perinatal Medicine 1987;15:112.

Ross M, Sandhu M, Bemis R, Nessim S, Bragonier J, Hobel C. The West Los Angeles preterm birth prevention project: II. Cost-effectiveness analysis of high-risk pregnancy interventions. Obstetrics \& Gynecology 1994;83:506-11.

Ross MG, Sandhu M, Bemis R, Nessim S, Bragonier JR, Mori B et al. West Los Angeles preterm birth prevention project (LAPPP): cost benefit of high risk 
pregnancy interventions. American Journal of Obstetrics and Gynecology 1992;166:367.

\section{Hoyer 1994}

Hoyer PJ, Jacobson M, Ford K, Walsh E. Pregnancy care for the adolescent. Nurse Practitioner 1994;19(4):27-8, 31-2.

\section{Ickovics 2007}

Ickovics JR, Kershaw TS, Westdahl C, Magriples U, Massey Z, Reynolds H, et al. Group prenatal care and perinatal outcomes: a randomized controlled trial. Obstetrics \& Gynecology 2007;110(2 Pt 1):330-9.

\section{Kitzman 2000}

Kitzman H, Olds DL, Sidora K, Henderson CR Jr, Hanks C, Cole R et al. Enduring effects of nurse home visitation on maternal life course: a 3-year follow-up of a randomized trial. JAMA 2000;283(15):1983-9.

\section{Koniak-Griffin 2000}

Koniak-Griffin D, Anderson NLR, Verzemnieks I, Brecht ML. A public health nursing early intervention program for adolescent mothers: outcomes from pregnancy through 6 weeks postpartum. Nursing Research 2000;49(3):130-8.

\section{Lee 2009}

Lee E, Mitchell-Herzfeld SD, Lowenfels AA, Greene R, Dorabawila V, DuMont KA. Reducing low birth weight through home visitation: a randomized controlled trial. American Journal of Preventive Medicine 2009;36(2):154-60.

\section{Little 2002}

Little M, Saul G, Testa K, Gaziano C. The influence of telephonic nursing care coordination on patient satisfaction in a predominantly low-income, high-risk pregnancy population. Lippincott's Case Management 2002;7:15-23.

* Little M, Saul GD, Testa K, Gaziano C. Improving pregnancy outcome and reducing avoidable clinical resource utilization through telephonic perinatal care coordination. Lippincott's Case Management 2002;7:103-12.

\section{Lumley 2006}

Lumley J, Donohue L. Aiming to increase birth weight: a randomised trial of pre-pregnancy information, advice and counselling in inner-urban Melbourne. BMC Public Health 2006;6:299.

\section{Nguyen 2003}


Nguyen JD, Carson ML, Parris KM, Place P. A comparison pilot study of public health field nursing home visitation program interventions for pregnant hispanic adolescents. Public Health Nursing 2003;20(5):412-8.

\section{Oakley 1996}

Oakley A, Hickey D, Rajan L, Rigby A. Social support in pregnancy: does it have long-term effects? Journal of Reproductive and Infant Pyschology 1996;14:7-22.

\section{Tough 2006}

* Tough SC, Johnston DW, Siever JE, Jorgenson G, Slocombe L, Lane C, et al. Does supplementary prenatal nursing and home visitation support improve resource use in a universal health care system? A randomized controlled trial in Canada. Birth 2006;33(3):183-94.

Tough SC, Johnston DW, Siever JE, Jorgenson G, Slocombe L, Lane C, et al. Does supplementary prenatal nursing and home visitation support improved resource utilization in a system of univeral health care? Results from a randomized controlled trial in Canada [abstract]. In: Pediatric Academic Societies Annual Meeting; 2006 April 29-May 2; San Fransisco, CA, USA. 2006.

\section{Studies awaiting classification}

Ongoing studies

\section{Other references}

Additional references

Berkowitz 1993

Berkowitz G, Papiernik E. Epidemiology of preterm birth. Epidemiologic Reviews 1993;15(2):414-43.

\section{Deeks 2001}

Deeks JJ, Altman DG, Bradburn MJ. Statistical methods for examining heterogeneity and combining results from several studies in meta-analysis. In: Egger M, Davey Smith G, Altman DG, editor(s). Systematic reviews in health care: meta-analysis in context. London: BMJ Books, 2001.

\section{Gates 2009}


Gates 2009. Methodological Guidelines. In: The Editorial Team. Pregnancy and Childbirth Group. About the Cochrane Collaboration (Collaborative Review Groups (CRGs)) 2009, Issue 1.

\section{Higgins 2005}

Higgins JPT, Green S, editors. Cochrane Handbook for Systematic Reviews of Interventions 4.2.5 [updated May 2005]. In: The Cochrane Library, Issue 3, 2005. Chichester, UK: John Wiley \& Sons, Ltd.

\section{Higgins 2008}

Higgins JPT, Green S, editors. Cochrane Handbook for Systematic Reviews of Interventions Version 5.0.1 [updated September 2008]. The Cochrane Collaboration, 2008. Available from www.cochrane-handbook.org.

\section{Hodnett 2007}

Hodnett ED, Gates S, Hofmeyr GJ, Sakala C. Continuous support for women during childbirth. Cochrane Database of Systematic Reviews 2007, Issue 3. Art. No.: CD003766. DOI: 10.1002/14651858.CD003766.pub2.

\section{Kramer 1987}

Kramer M. Determinants of low birth weight: methodological assessment and meta-analysis. Bulletin of the World Health Organisation 1987;65:663-737.

\section{Kramer 2003}

Kramer MS, Kakuma R. Energy and protein intake in pregnancy. Cochrane Database of Systematic Reviews 2003, Issue 4. Art. No.: CD000032. DOI: 10.1002/14651858.CD000032.

\section{Lumley 2004}

Lumley J, Oliver S, Chamberlain C, Oakley L. Interventions for promoting smoking cessation during pregnancy. Cochrane Database of Systematic Reviews 2004, Issue 4. Art. No.: CD001055. DOI:

10.1002/14651858.CD001055.pub2.

\section{Mahomed 1999}

Mahomed K, Gulmezoglu AM. Vitamin D supplementation in pregnancy. Cochrane Database of Systematic Reviews 1999, Issue 1. Art. No.: CD000228. DOI: 10.1002/14651858.CD000228.

\section{Marc 2009}


Marc I, Blanchet C, Ernst E, Hodnett ED, Turcot L, Dodin S. Mind-body interventions during pregnancy for preventing or treating women's anxiety [Protocol]. Cochrane Database of Systematic Reviews 2009, Issue 1. Art. No.: CD007559. DOI: 10.1002/14651858.CD007559.

\section{McDonald 2007}

McDonald HM, Brocklehurst P, Gordon A. Antibiotics for treating bacterial vaginosis in pregnancy. Cochrane Database of Systematic Reviews 2007, Issue 1. Art. No.: CD000262. DOI: 10.1002/14651858.CD000262.pub3.

\section{Norbeck 1983}

Norbeck JS, Tilden VP. Life stress, social support, and emotional disequilibrium in complications of pregnancy: a prospect, multivariate study. Journal of Health and Social Behaviour 1983;24:30-6.

\section{Reveiz 2007}

Reveiz L, Gyte GML, Cuervo LG. Treatments for iron-deficiency anaemia in pregnancy. Cochrane Database of Systematic Reviews 2007, Issue 2. Art. No.: CD003094. DOI: 10.1002/14651858.CD003094.pub2.

\section{RevMan 2008}

Review Manager (RevMan) [Computer program]. Version 5.0. Copenhagen, The Nordic Cochrane Centre: The Cochrane Collaboration, 2008.

\section{Say 1996a}

Say L, Gülmezoglu AM, Hofmeyr GJ. Calcium channel blockers for potential impaired fetal growth. Cochrane Database of Systematic Reviews 1996, Issue 1. Art. No.: CD000049. DOI: 10.1002/14651858.CD000049.

\section{Say 1996b}

Say L, Gülmezoglu AM, Hofmeyr GJ. Plasma volume expansion for suspected impaired fetal growth. Cochrane Database of Systematic Reviews 1996, Issue 4. Art. No.: CD000167. DOI: 10.1002/14651858.CD000167.

\section{Say 2001}

Say L, Gülmezoglu AM, Hofmeyr GJ. Betamimetics for suspected impaired fetal growth. Cochrane Database of Systematic Reviews 2001, Issue 4. Art. No.: CD000036. DOI: 10.1002/14651858.CD000036.

\section{Say 2003}


Say L, Gülmezoglu AM, Hofmeyr GJ. Maternal nutrient supplementation for suspected impaired fetal growth. Cochrane Database of Systematic Reviews 2003, Issue 1. Art. No.: CD000148. DOI: 10.1002/14651858.CD000148.

\section{Smaill 2007}

Smaill FM, Vazquez JC. Antibiotics for asymptomatic bacteriuria in pregnancy. Cochrane Database of Systematic Reviews 2007, Issue 2. Art. No.:

CD000490. DOI: 10.1002/14651858.CD000490.pub2.

\section{Wilkins 1991}

Wilkins R, Sherman G, Best P. Birth outcomes and infant mortality by income in urban Canada, 1986. Health Report 1991;3:7-31.

\section{Other published versions of this review CDSR 2003}

Hodnett ED. Support during pregnancy for women at increased risk of low birthweight babies. Cochrane Database of Systematic Reviews 2003, Issue 3. Art. No.: CD000198. DOI: 10.1002/14651858.CD000198.

\section{Classification pending references}

\section{Data and analyses}

\section{Additional support versus usual care during at-risk pregnancy}

\begin{tabular}{|c|c|c|c|c|}
\hline Outcome or Subgroup & Studies & Partici & nts Statistical Method & Effect Estimate \\
\hline 1.1 Miscarriage & 4 & 4195 & $\begin{array}{l}\text { Risk Ratio (M-H, Fixed, } \\
95 \% \text { CI) }\end{array}$ & $0.99[0.73,1.35]$ \\
\hline $\begin{array}{l}1.2 \text { Termination of } \\
\text { pregnancy }\end{array}$ & 4 & 4195 & $\begin{array}{l}\text { Risk Ratio (M-H, Fixed, } \\
95 \% \text { CI) }\end{array}$ & $2.96[1.42,6.17]$ \\
\hline 1.3 Antenatal anxiety score & 1 & 60 & $\begin{array}{l}\text { Mean Difference (IV, Fixed, } \\
95 \% \text { CI) }\end{array}$ & $\begin{array}{l}-7.85[-13.14,- \\
2.56]\end{array}$ \\
\hline $\begin{array}{l}\text { 1.4 Less than very satisfied } \\
\text { with antenatal care }\end{array}$ & 1 & 158 & $\begin{array}{l}\text { Risk Ratio (M-H, Fixed, } \\
95 \% \text { CI) }\end{array}$ & $0.42[0.25,0.73]$ \\
\hline 1.5 Antenatal depression & 1 & 509 & $\begin{array}{l}\text { Risk Ratio (M-H, Fixed, } \\
95 \% \text { CI) }\end{array}$ & $0.77[0.50,1.19]$ \\
\hline $\begin{array}{l}\text { 1.6 Antenatal hospital } \\
\text { admission }\end{array}$ & 6 & 1933 & $\begin{array}{l}\text { Risk Ratio (M-H, Random, } \\
95 \% \text { CI) }\end{array}$ & $0.86[0.68,1.08]$ \\
\hline 1.7 Antenatal hypertension & 1 & 509 & $\begin{array}{l}\text { Risk Ratio (M-H, Fixed, } \\
95 \% \text { CI) }\end{array}$ & $0.95[0.55,1.66]$ \\
\hline 1.8 Intrapartum & 3 & 4032 & Risk Ratio (M-H, Fixed, & $0.94[0.89,1.00]$ \\
\hline
\end{tabular}




\begin{tabular}{|c|c|c|c|c|}
\hline analgesia/anaesthesia & & & $95 \% \mathrm{CI})$ & \\
\hline 1.9 Induction of labour & 4 & 1065 & $\begin{array}{l}\text { Risk Ratio (M-H, Fixed, } \\
95 \% \text { CI) }\end{array}$ & $0.91[0.77,1.07]$ \\
\hline 1.10 Caesarean birth & 9 & 5108 & $\begin{array}{l}\text { Risk Ratio (M-H, Fixed, } \\
95 \% \text { CI) }\end{array}$ & $0.88[0.79,0.98]$ \\
\hline $\begin{array}{l}1.11 \text { Instrumental vaginal } \\
\text { birth }\end{array}$ & 6 & 5533 & $\begin{array}{l}\text { Risk Ratio (M-H, Fixed, } \\
95 \% \text { CI) }\end{array}$ & $1.01[0.89,1.14]$ \\
\hline $\begin{array}{l}1.12 \text { Gestational age }<37 \\
\text { weeks at birth }\end{array}$ & 11 & 10237 & $\begin{array}{l}\text { Risk Ratio (M-H, Fixed, } \\
95 \% \text { CI) }\end{array}$ & $0.96[0.86,1.07]$ \\
\hline 1.13 Gestational age at birth 5 & 5 & 2152 & $\begin{array}{l}\text { Mean Difference (IV, Fixed, } \\
95 \% \text { CI) }\end{array}$ & $0.17[-0.06,0.40]$ \\
\hline 1.14 Birthweight $<1500 \mathrm{gm} 3$ & 3 & 2428 & $\begin{array}{l}\text { Risk Ratio (M-H, Fixed, } \\
95 \% \text { CI) }\end{array}$ & $0.72[0.47,1.09]$ \\
\hline 1.15 Birthweight $<2500 \mathrm{gm} 1$ & 13 & 10235 & $\begin{array}{l}\text { Risk Ratio (M-H, Fixed, } \\
95 \% \text { CI) }\end{array}$ & $0.98[0.89,1.08]$ \\
\hline 1.16 Birthweight (gm) & 6 & 3029 & $\begin{array}{l}\text { Mean Difference (IV, } \\
\text { Random, 95\% CI) }\end{array}$ & $\begin{array}{l}20.88[-53.35 \\
95.11]\end{array}$ \\
\hline $\begin{array}{l}\text { 1.17 Small-for-gestational } \\
\text { age }\end{array}$ & 2 & 3523 & $\begin{array}{l}\text { Risk Ratio (M-H, Fixed, } \\
95 \% \text { CI) }\end{array}$ & $1.05[0.88,1.26]$ \\
\hline $\begin{array}{l}1.18 \text { Stillbirth/neonatal } \\
\text { death }\end{array}$ & 11 & 9507 & $\begin{array}{l}\text { Risk Ratio (M-H, Fixed, } \\
95 \% \text { CI) }\end{array}$ & $1.15[0.89,1.51]$ \\
\hline $\begin{array}{l}1.19 \text { Apgar score }<7 \text { at } 1 \\
\text { minute }\end{array}$ & 3 & 1209 & $\begin{array}{l}\text { Risk Ratio (M-H, Fixed, } \\
95 \% \text { CI) }\end{array}$ & $0.81[0.60,1.09]$ \\
\hline $\begin{array}{l}\text { 1.20 Apgar score }<7 \text { at } 5 \\
\text { minutes }\end{array}$ & 4 & 3444 & $\begin{array}{l}\text { Risk Ratio (M-H, Fixed, } \\
95 \% \text { CI) }\end{array}$ & $0.99[0.61,1.61]$ \\
\hline $\begin{array}{l}\text { 1.21 Newborn respiratory } \\
\text { distress }\end{array}$ & 1 & 509 & $\begin{array}{l}\text { Risk Ratio (M-H, Fixed, } \\
95 \% \text { CI) }\end{array}$ & $0.54[0.22,1.32]$ \\
\hline $\begin{array}{l}\text { 1.22 Admission to neonatal } \\
\text { intensive care nursery }\end{array}$ & 4 & 3467 & $\begin{array}{l}\text { Risk Ratio (M-H, Fixed, } \\
95 \% \text { CI) }\end{array}$ & $0.92[0.77,1.09]$ \\
\hline \begin{tabular}{|l|}
1.23 Absence of other help \\
at home
\end{tabular} & 1 & 158 & $\begin{array}{l}\text { Risk Ratio (M-H, Fixed, } \\
95 \% \text { CI) }\end{array}$ & $0.39[0.21,0.73]$ \\
\hline $\begin{array}{l}\text { 1.24 Postnatal physical } \\
\text { problems }\end{array}$ & 1 & 509 & $\begin{array}{l}\text { Risk Ratio (M-H, Fixed, } \\
95 \% \text { CI) }\end{array}$ & $0.93[0.85,1.03]$ \\
\hline $\begin{array}{l}\text { 1.25 Postnatal re- } \\
\text { hospitalization }\end{array}$ & 2 & 682 & $\begin{array}{l}\text { Risk Ratio (M-H, Random, } \\
95 \% \text { CI) }\end{array}$ & $0.92[0.31,2.76]$ \\
\hline 1.26 Poor postnatal health & 1 & 509 & $\begin{array}{l}\text { Risk Ratio (M-H, Fixed, } \\
95 \% \text { CI) }\end{array}$ & $0.77[0.59,1.00]$ \\
\hline $\begin{array}{l}\text { 1.27 Prefer hospitalization in } 1 \\
\text { at-risk pregnancy }\end{array}$ & & 158 & $\begin{array}{l}\text { Risk Ratio (M-H, Fixed, } \\
95 \% \text { CI) }\end{array}$ & $0.88[0.33,2.30]$ \\
\hline $\begin{array}{l}\text { 1.28 Feeling low control } \\
\text { postnatally }\end{array}$ & 1 & 509 & $\begin{array}{l}\text { Risk Ratio (M-H, Fixed, } \\
95 \% \text { CI) }\end{array}$ & $0.78[0.59,1.03]$ \\
\hline 1.29 Feeling worried about 1 & 1 & 509 & Risk Ratio (M-H, Fixed, & $0.57[0.39,0.82]$ \\
\hline
\end{tabular}




\begin{tabular}{|l|l|l|l|l|}
\hline baby & & & $\begin{array}{l}95 \% \text { CI) } \\
\text { Risk Ratio (M-H, Fixed, } \\
95 \% \text { CI) }\end{array}$ & $0.86[0.69,1.06]$ \\
\hline $\begin{array}{l}\text { 1.31 Additional health } \\
\text { service use }\end{array}$ & 1 & 509 & $\begin{array}{l}\text { Risk Ratio (M-H, Fixed, } \\
95 \% \text { CI) }\end{array}$ & $0.88[0.76,1.02]$ \\
\hline
\end{tabular}

\section{Figures}

\section{Sources of support}

\section{Internal sources}

- University of Toronto, Canada

- Ryerson University, Canada

\section{External sources}

- No sources of support provided

\section{Feedback}

\section{Appendices}

\section{Methods used to assess trials included in previous versions of this review}

The following methods were used to assess Blondel 1990; Brooten 2001; Bryce 1991; Dawson 1989; Dawson 1999; Heins 1990; ledema-Kuiper 1996; Klerman 2001; Klerman 2001; McLaughlin 1992; Moore 1998; Norbeck 1996; Oakley 1990; Olds 1986; Rothberg 1991a; Rothberg 1991b; Spencer 1989; Spira 1986; Villar 1993.

We processed included trial data as described in Higgins 2005. We assigned quality scores for allocation concealment to each trial, where $A=$ adequate, $B$ $=$ unclear,$C=$ inadequate, and $D=$ not used. Studies rated as a $D$ were excluded. Wherever necessary, we requested unpublished data from the trial authors. For all data analyses in this Review, we entered data based on the principle of intention to treat. To be included in a given comparison, outcome data had to be available for at least $80 \%$ of those who were randomized.

In trials in which some participants have interventions such as prenatal and infancy home visitation prior to enrollment, only those interventions which occurred after randomization were included in the data tables. In trials that 
included women with multiple pregnancies (eg twins), the pregnancy was the unit of analysis. Thus, an adverse outcome for one baby was counted as an adverse outcome of that pregnancy, and if both babies had an adverse outcome (eg preterm birth), it was counted as a single outcome.

We performed double-data entry, and the results were compared until $100 \%$ agreement was achieved.

We calculated relative risks as the measures of effect size for binary outcomes. We used weighted mean differences for most continuous outcome measures. If trials had used different ways of measuring the same outcome, standardized mean differences were to be used. Scores from rating scales were either analysed as continuous variables, if the scale was sufficiently long for this to be reasonable, or converted to dichotomous variables. Fixed-effect meta-analysis was used for combination of studies if the trials were sufficiently similar in their design and interventions that a fixed-effect summary would be meaningful. When there were differences between the trials that were likely to lead to differences in their treatment effects, we used a random-effects metaanalysis. We performed tests for heterogeneity, and when heterogeneity was identified, either by a significant result $(P<0.1)$ or obvious inconsistency of the effect sizes of the trials in the analysis, a random-effects analysis was preferred. We investigated biases in the studies included in the analyses by means of funnel plots and through sensitivity analyses comparing the results when lower quality trials were excluded.

A subgroup analysis is planned to compare support provided by lay women versus support by healthcare professionals, because another Review of support for childbearing women (Hodnett 2007) found differences in the effects of support by hospital staff (nurses, midwives) versus support by lay women. The pre-specified outcomes for inclusion in the subgroup analysis are gestational age $<37$ weeks and birthweight $<2500 \mathrm{gm}$. 